TAPROBANICA, ISSN 1800-427X. November, 2020. Vol. 09, No. 02: pp. 136-163, pl. 46-48.

(C) Research Center for Climate Change and Department of Biology, Faculty of Mathematics \& Natural Sciences, University of Indonesia, Depok 16424, INDONESIA.

http://www.taprobanica.org/

https://doi.org/10.47605/tapro.v9i2.228

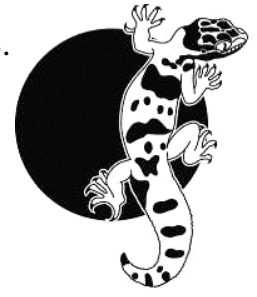

urn:Isid:zoobank.org:pub: 821DADE0-4D03-4B13-A1DD-AAF80A56AB68

\title{
A NEW CRYPTIC SPECIES OF THE GENUS Microhyla (AMPHIBIA: MICROHYLIDAE) FROM LANGBIAN PLATEAU, VIETNAM
}

\author{
Nikolay A. Poyarkov ${ }^{1,3}$, Tan Van Nguyen $^{2}$, Alexey V. Trofimets ${ }^{1} \&$ Vladislav A. Gorin ${ }^{1,4}$ \\ ${ }^{1}$ Department of Vertebrate Zoology, Biological Faculty, Lomonosov Moscow State University, Moscow, Russia \\ ${ }^{2}$ Department of Species Conservation, Save Vietnam's Wildlife Center, Ninh Binh, Vietnam \\ ${ }^{3}$ Joint Russian-Vietnamese Tropical Research and Technological Center, Hanoi, Vietnam \\ Corresponding authors.E-mails: n.poyarkov@gmail.com ${ }^{3}$; gorinvlad@gmail.com ${ }^{4}$
}

\begin{abstract}
An integrative taxonomic analysis combining molecular and morphological lines of evidence revealed a new cryptic species of the Microhyla achatina species group from the Langbian Plateau of southern Vietnam. The new species was previously confused with its recently described morphologically similar and sympatric sister species, $M$. pineticola. The new species can be distinguished from $M$. pineticola by the presence of a continuous dark stripe running from the posterior edge of its eye towards the groin ( $v s$ dark markings interrupted above the axilla), snout acuminate in lateral profile ( $v s$ rounded), belly colour pattern, and foot webbing. The new species is currently known only from Bidoup-Nui Ba National Park in Lam Dong Province, Langbian Plateau in southern Vietnam (at elevations of 1300-1600 m a.s.l). We suggest the new species to be considered as Near Threatened (NT) in the IUCN Red List. Our results emphasize that our understanding of the diversity of genus Microhyla is still far from complete, and provide further evidence for montane areas of southern Vietnam to be a centre of Microhyla species richness. Our study further underscores the urgent need for intensified integrative taxonomic research on Microhyla spp. in order to clarify the taxonomy of wide-ranging species complexes and to elaborate effective conservation measures.
\end{abstract}

Key words: Bidoup-Nui Ba National Park, Microhyla pineticola, mtDNA, sympatry, taxonomy.

\section{Introduction}

The genus Microhyla Tschudi, 1838 currently contains 52 nominal species of small-sized to tiny terrestrial frogs distributed from the Ryukyus (Japan) and southern China, southward through Southeast Asia to India and Sri Lanka (Frost 2020; Gorin et al. 2020; Poyarkov et al. 2020a,b). Nearly one half (23 species) of the recognised members of this diverse genus has been described within the last 10 years (Frost 2020). Nevertheless the taxonomy of Microhyla remains challenging, owing to logistical problems associate with their small size. Taxonomic progress in Microhyla is further hampered by the independent evolution of miniaturization observed in several lineages and the resulting high degree of convergent morphological similarity (Gorin et al. 2020). 
This, along with the common sympatric occurrences of closely-related cryptic species and widely distributed complexes comprised of highly divergent lineages (Garg et al. 2018; Gorin et al. 2020), make the genus Microhyla one the most taxonomically challenging groups of Asian frogs. Thus, the application of molecular phylogenetics is crucial for the construction of a proper taxonomy and understanding the diversity within Microhyla (Gorin et al. 2020).

The Pine narrow-mouth frog, Microhyla pineticola Poyarkov, Vassilieva, Orlov, et al., 2014 was described from Bidoup-Nui Ba National Park in Lam Dong Province, Langbian Plateau in southern Vietnam. In their study, Poyarkov et al. (2014) revised the Microhyla fauna of Vietnam based entirely on morphological evidence, and distinguished $M$. pineticola from the morphologically similar $M$. heymonsi Vogt, 1911, a widely distributed species found throughout Indochina. A more recent comprehensive review of Microhyla diversity and phylogenetic relationships (Gorin et al. 2020) confirmed the genetic distinctiveness of $M$. pineticola from $M$. heymonsi, and assigned both species to the $M$. achatina species group (group A in Gorin et al. 2020). According to the original description, $M$. pineticola is characterized by: a small dark round spot at the mid-dorsum divided by a light vertebral stripe and dorsal markings formed by dark-brown lines outlined in beige, parallel to the vertebral and dorsolateral stripes, forming a pattern resembling the grain of pinewood (Poyarkov et al. 2014). Poyarkov et al. (2014) reported significant variation in colouration within the type series of $M$. pineticola, which included specimens lacking the characteristic lines on dorsum, and specimens having a dark line extending from the posterior margin of the eye towards the flanks and groin which may or may not be continuous be interrupted above the axilla (see variation section in Poyarkov et al. 2014: 103-104). However, additional data on the morphological variation and the molecular differentiation of the populations assigned to $M$. pineticola were lacking.

While collecting genetic data for the phylogenetic reconstruction by Gorin et al. (2020), we discovered that the samples of $M$. pineticola were represented by two highly divergent haplotypes (only one of which was included in the final analysis of Gorin et al. 2020). In the present study we apply an integrative taxonomic approach, comparing the results of morphological analyses with those of phylogenetic analyses using mitochondrial (mtDNA) sequences (12S rRNA-16S rRNA fragment) to analyze differentiation between $M$. pineticola populations from Lam Dong Province and the newly discovered population from Dak Lak Province of southern Vietnam. We demonstrate that the type series of $M$. pineticola is comprised of two superficially similar yet genetically different cryptic lineages of individuals. Additional examination of the type series and newly collected material resulted in the discovery of stable character state differences in colouration and external morphology between the two lineages which are concordant with the results of the molecular phylogenetic analyses. Herein, we reassess the taxonomic status of the two lineages masquerading under the name ' $M$. pineticola': one is redescribed as $M$. pineticola s. str., while the second we describe as a new, previously overlooked, cryptic species of Microhyla.

\section{Material and methods}

Sample collection: We examined the type series of Microhyla pineticola stored in the Zoological Museum of Moscow University (Moscow, Russia; hereafter given as ZMMU), including the holotype specimen (ZMMU A-5043). Additional specimens were collected from Lam Dong and Dak Lak provinces, southern Vietnam, during several field surveys in 2009-2014 (Table 1). The locations of the surveyed localities and the distribution of $M$. pineticola complex members in Vietnam are shown in Fig. 1. Geographic coordinates and elevations were obtained using a Garmin GPSMAP 60CSx (WGS 84 datum). Specimens were fixed in $10 \%$ buffered formalin after tissue samples were preserved in $95 \%$ ethanol. Specimens were later transferred to $70 \%$ ethanol. Newly collected specimens and tissues were subsequently deposited in the herpetological collections of ZMMU (Moscow, Russia).

Morphological description: Specimens of the Microhyla pineticola complex were photographed in life and after preservation. Measurements were taken using a digital caliper to the nearest $0.01 \mathrm{~mm}$ and rounded to $0.1 \mathrm{~mm}$. We used an Olympus stereoscopic light binocular microscope when necessary. All measurements were taken on the right side of the specimen. The morphometrics of adults and character terminology followed Poyarkov et al. 
(2014, 2019a, 2020a,b) and included the following measurements: snout-vent length (SVL; measured from tip of snout to cloaca); head length (HL; measured from tip of snout to hind border of jaw angle); snout length (SL; measured from anterior margin of eye to tip of snout); eye length (EL; measured as the distance between anterior and posterior margins of the eye); nostril-eye length (N-EL; measured as the distance between the anterior margin of the eye and the nostril centre); head width (HW; measured as the maximum width of the head at the level of mouth angles in ventral view); internarial distance (IND; measured as the distance between central points of nostrils); interorbital distance (IOD; measured as the shortest distance between medial edges of eyeballs in dorsal view); upper eyelid width (UEW; measured as the maximum distance between medial edge of eyeball and lateral edge of upper eyelid); forelimb length (FLL; measured as the length of straightened forelimb to tip of third finger); lower arm and hand length (LAL; measured as the distance between elbow and tip of third finger); hand length (HAL; measured as the distance between proximal end of outer palmar (metacarpal) tubercle and tip of third finger); first finger length (1FL, measured as the distance between tip and distal end of inner palmar tubercle); inner palmar tubercle length (IPTL; measured as the maximum distance between proximal and distal ends of inner palmar tubercle); outer palmar tubercle length (OPTL; measured as the maximum diameter of outer palmar tubercle); third finger disc diameter (3FDD); hindlimb length (HLL; measured as the length of straightened hindlimb from groin to tip of fourth toe); tibia length (TL; measured as the distance between knee and tibiotarsal articulation); foot length (FL; measured as the distance between distal end of tibia and tip of fourth toe); inner metatarsal tubercle length (IMTL; measured as the maximum length of inner metatarsal tubercle); first toe length (1TOEL), measured as the distance between distal end of inner metatarsal tubercle and tip of first toe; third toe disc diameter (3TDD); outer metatarsal tubercle length (OMTL; measured as the maximum length of outer metatarsal tubercle). Additionally, we took the following measurements for the holotype description: second to fourth finger lengths (2-3FLO, 4FL-I; for outer side $(\mathrm{O})$ of the second and third, and inner side (I) of the fourth, measured as the distance between the tip and junction of the neighboring finger); second to fifth toe lengths (measured as the outer lengths for toes II-IV, as the inner length for toe $\mathrm{V}$; 2-5TOEL); finger disc diameter for fingers I-II and IV (1-2FDD, 4FDD); toe disc diameter for toes I-II and IV-V (1-2TDD, 4-5TDD). Toe webbing and subarticular tubercle formulas were given following Savage (1975). The sex and maturity of the specimens was checked by minor dissections and by direct observations of calling behaviour in living males prior to collection.

The diagnosis of the genus Microhyla and morphological characters for comparison were taken from original descriptions and taxonomic reviews from: Atmaja et al. (2019); Bain \& Nguyen (2004); Biju et al. (2019); Das \& Haas (2010); Das et al. (2007); Garg et al. (2018); Hasan et al. (2014); Hoang et al. (2020); Howlader et al. (2015); Khatiwada et al. (2017); Matsui (2011); Matsui et al. (2013); Matsui \& Tomiaga (2020); Nguyen et al. (2019); Li et al. (2019); Parker (1928); Pillai (1977); Poyarkov et al. (2014, 2019a, 2020a,b); Vineeth et al. (2018); Wijayathilaka et al. (2016); Zhang et al. (2018).

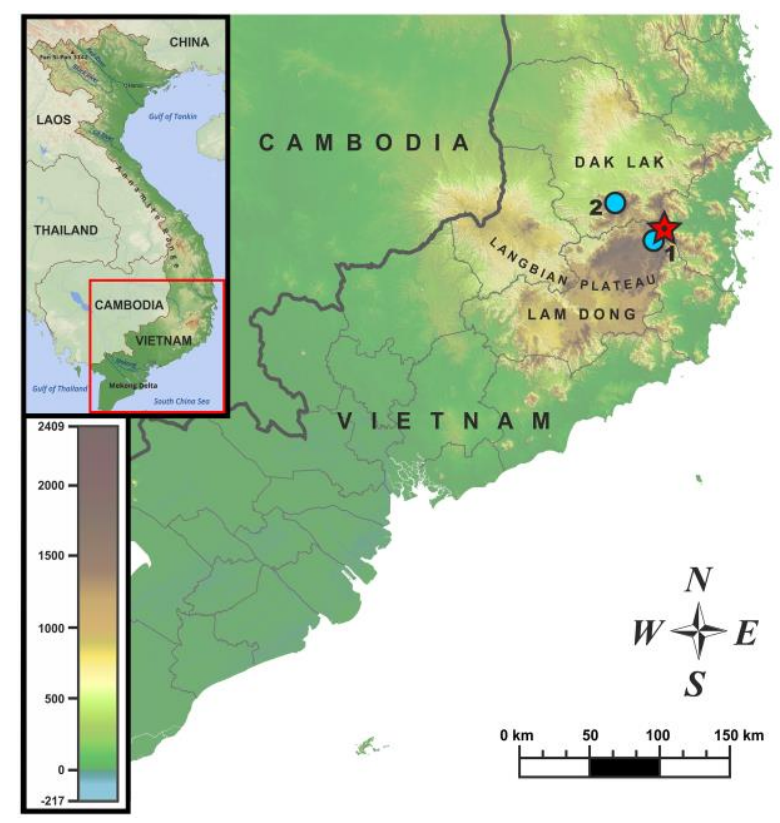

Figure 1. Distribution of Microhyla pineticola sensu stricto (circles) and the new species (star) in southern Vietnam; 1, Bidoup-Nui Ba National Park, Lam Dong Province; 2, Chu Yang Sin National Park, Dak Lak Province.

Laboratory methods: Total genomic DNA was extracted from ethanol-preserved femoral muscle tissue or liver tissue using a standard phenol-chloroform-proteinase $\mathrm{K}$ extraction protocol with consequent isopropanol precipitation (Hillis et al. 1996). Isolated 
genomic DNA was visualized in agarose electrophoresis in the presence of ethidium bromide; total DNA concentration was measured in $1 \mu \mathrm{L}$ using NanoDrop 2000 (Thermo Scientific), and consequently adjusted to $175 \mathrm{ca}$. $100 \mathrm{ng} \mathrm{DNA} / \mu \mathrm{L}$. We amplified an mtDNA fragment partially covering the $12 \mathrm{~S}$ rRNA-16S rRNA genes and the complete sequence of tRNA-Val resulting in a continuous fragment $2399 \mathrm{bp}$ in length. These markers have proven to be particularly useful in phylogenetic and taxonomic studies of the genus Microhyla (e.g. Matsui 2011; Hasan et al. 2012, 2014; Matsui et al. 2013; Wijayathilaka et al. 2016; Poyarkov et al. 2019a, 2020b; Gorin et al. 2020). DNA amplification was performed in $20-\mu \mathrm{L}$ reactions using ca. $50 \mathrm{ng}$ genomic DNA, $10 \mathrm{nmol}$ of each primer, $15 \mathrm{nmol}$ of each dNTP, $50 \mathrm{nmol}$ additional $\mathrm{MgCl}$, Taq PCR buffer $(10 \mathrm{mM}$ Tris-HCl, $\mathrm{pH} 8.3,50 \mathrm{mM} \mathrm{KCl}, 1.1 \mathrm{mM} \mathrm{MgCl} 2$ and $0.01 \%$ gelatine) and $1 \mathrm{U}$ of $185 \mathrm{Taq}$ DNA polymerase. Primers used in PCR and sequencing, along with the PCR conditions followed Gorin et al. (2020). The PCR products were loaded onto $1.5 \%$ agarose gels in the presence of ethidium bromide and visualised in electrophoresis. The successful targeted PCR products were outsourced to Evrogen ${ }^{\circledR}$ (Moscow, Russia) for PCR purification and sequencing. Sequence data collection and visualisation were carried out on an ABI 3730xl Automated Sequencer (Applied Biosystems). The newly obtained sequences were deposited in GenBank under accession numbers MW147155-MW147166 and MW147168MW147172 (Table 1).

Phylogenetic analyses: The 12S rRNA-16S rRNA Microhylidae data set of Gorin et al. (2020) with the addition of a sequence of the recently described $M$. hongiaoensis Hoang, Luong, Nguyen et al. 2020 and our newly obtained sequences were used to reconstruct a matrilineal genealogy of Microhyla. The initial data set was pruned to one sequence per species, with the exception of $M$. pineticola and the morphologically similar Microhyla sp. from southern Vietnam. In total, 12S rRNA-16S rRNA data for 93 specimens were included in the final analysis, including 64 samples of ca. 53 Microhyla species (representing all recognized species within the genus), 28 outgroup sequences of other microhylid representatives, and a sequence of Rhacophorus schlegelii (Günther, 1858), which was used to root the tree (Table 1). We initially aligned the nucleotide sequences in MAFFT v. 6 (Katoh et al. 2002) with default parameters, and subsequently slightly adjusted it in BioEdit v. 7.0.5.2 (Hall 1999). The mean uncorrected genetic distances (p-distances) between individuals were estimated in MEGA 6.0 (Tamura et al. 2013). We used IQ-TREE webserver (Nguyen et al. 2015; Trifinopoulos et al. 2016) to estimate the optimal evolutionary models for the subsequent analyses. The best-fitting models of DNA evolution were GTR+I $+\mathrm{G}, \mathrm{JC}+\mathrm{G}$ and $\mathrm{GTR}+\mathrm{G}$, for 12S rRNA, tRNA-Val and 16S rRNA genes, respectively, as suggested by the Akaike information criterion (AICc).

We inferred the matrilineal genealogy using Maximum Likelihood (ML) and Bayesian Inference (BI) approaches. We conducted ML analysis in the IQ-TREE webserver. Onethousand bootstrap pseudoreplicates via the ultrafast bootstrap (UFBS; Hoang et al. 2018) approximation algorithm were employed and nodes having ML UFBS values of 95 and above were considered highly supported, while the nodes with values of 90-94 were considered well-supported (Bui et al. 2013). We implemented the BI analysis in MrBayes v. 3.1.2 (Ronquist \& Huelsenbeck 2003). We ran Metropolis-coupled Markov chain Monte Carlo (MCMCMC) analyses with one cold and three heated chains for 20 million generations and sampled every 2,000 generations. The two independent MCMCMC runs were performed; we checked that the effective sample sizes (ESSs) were all above 200 by exploring the likelihood plots using TRACER v. 1.6 (Rambaut et al. 2014). The initial 1000 trees were discarded as burn-in. The confidence in tree topology was assessed by the frequency of nodal resolution (posterior probability; BI PP) (Huelsenbeck \& Ronquist 2001). We regarded tree nodes with BIPP values over 0.95 to be strongly supported; values between 0.95 and 0.90 were regarded as moderately supported; while the lower values were considered to have no nodal support (Huelsenbeck \& Hillis 1993).

\section{Results}

Sequence variation: Among the $2399 \mathrm{bp}$ of the final 12S rRNA-16S rRNA alignment, 1295 sites were conserved, while 1101 sites exhibited variation, of which 847 were parsimony informative. The transition-transversion bias (R) was estimated as 2.11. Nucleotide frequencies were $\mathrm{A}=33.60 \%, \mathrm{~T}=24.30 \%, \mathrm{C}=23.63 \%$, and $\mathrm{G}=18.47 \%$ (data given for ingroup only). 
MtDNA genealogy: The ML and BI analyses resulted in identical topologies, which differed only in a non-supported node of the basal radiation of Microhyla (Fig. 2). Both analyses achieved high resolution of phylogenetic relationships among Microhyla species and all major nodes in the tree were sufficiently resolved (UFBS $\geq 95 \%$; $P P \geq 0.95$ ). Overall, our updated mtDNA genealogy was largely consistent with the phylogeny of Gorin $e t$ al. (2020), suggesting strong support for monophyly of the Microhyla-Glyphoglossus assemblage (100/1.0; hereafter nodal support values given for UFBS/PP, respectively), and no support for Microhyla monophyly (53/-). Within the Microhyla-Glyphoglossus assemblage, ten major clades / lineages were recovered, generally agreeing with the results of Gorin et al. (2020) (Fig. 2, hereafter species group names follow Gorin et al. 2020). Clade A consisted of 15 morphospecies of the $M$. achatina species group, including $M$. achatina Tschudi, 1838; $M$. heymonsi; M. borneensis Parker, 1928; M. gadjahmadai Atmaja, Hamidy, Arisuryanti et al., 2018; M. irrawaddy Poyarkov, Gorin, Zaw et al. 2019; M. kodial Vineeth, Radhakrishna, Godwin et al., 2018; M. malang Matsui, 2011; M. mantheyi Das, Yaakob \& Sukumaran, 2007; $M$. minuta Poyarkov, Vassilieva, Orlov et al., 2014; M. nepenthicola Das \& Haas, 2010; M. orientalis Matsui, Hamidy \& Eto, 2013; the two undescribed species-level lineages Microhyla sp. 1 from Sarawak, Malaysia, and Microhyla sp. 2 from Sagaing, Myanmar, and the two lineages of ' $M$. pineticola' from southern Vietnam (Fig. 2, Clade A). The phylogenetic relationships and taxonomic content of other species groups (Clades B-J) fully agreed with the results of Gorin et al. (2020), including the M. fissipes group (Clade $\mathrm{B}$ ), the $M$. berdmorei group (Clade D), the $M$. superciliaris group (Clade E), the $M$. ornata group (Clade F), the $M$. butleri group (Clade G), M. palmipes Boulenger (Clade H), the $M$. annectens group (Clade I), and Glyphoglossus Günther (Clade J) (see Fig. 2 for details). The only important difference from the taxonomic arrangement by Gorin et al. (2020) is the phylogenetic position of $M$. fodiens Poyarkov, Gorin, Zaw et al., 2019 from Myanmar, which was earlier provisionally assigned to the $M$. achatina species group (Poyarkov et al. 2019a; Gorin et al. 2020). In our mtDNA-genealogy $M$. fodiens is an orphaned species, suggested as a sister lineage $(100 / 1.0)$ to the moderately supported clade joining the members of $M$. achatina species group + M. fissipes groups (93/0.62) (Fig. 2, Clade C). Genealogical relationships within the $M$. achatina species group were generally sufficiently resolved, suggesting that all members of this group with the exception of $M$. heymonsi and ' $M$. pineticola' form a strongly supported clade (100/1.0), joining species from Sundaland, Myanmar, and southern India. The only Vietnamese taxon in this clade is $M$. minuta and it is distantly related to the other species. The wide-ranging $M$. heymonsi formed a strongly supported ML clade with ' $M$. pineticola' from southern Vietnam, but and unsupported clade in in the BI analysis (97/0.89).

Our analysis strongly suggested that ' $M$. pineticola' from southern Vietnam is represented by two, highly divergent, reciprocally monophyletic, sympatric lineages (100/1.0). One lineage corresponds to $M$. pineticola sensu stricto and includes the holotype of M. pineticola (ZMMU A-5043), two paratypes (ZMMU A-5080, A-4331) (all three specimens from Bidoup-Nui Ba National Park, Lam Dong Province; Fig. 1, locality 1), and two newly collected specimens from Chu Yang Sin National Park, Dak Lak Province (ZMMU A6029, A-7269; Fig. 1, locality 2) (Fig. 2). The other lineage includes eight specimens from the same area of Bidoup-Nui Ba National Park as the $M$. pineticola holotype-all of which were indentified by Poyarkov et al. (2014) as paratypes of ' $M$. pineticola' (originally listed under numbers ZMMU A-4331 and A-5080; new numbers ZMMU A-7302-7306, A-7308, A-7310-7311) (Fig. 2).

Genetic distances: The uncorrected pdistances for the 16S rRNA mtDNA fragment among the members of the $M$. achatina species group are shown in Table 2. The interspecific distances among the members of the $M$. achatina species group varied from $p=2.2 \%$ (between M. irrawaddy and Microhyla sp. 2) to $p=14.5 \%$ (between $M$. fodiens and $M$. borneensis). The two lineages of ' $M$. pineticola' showed a significant level of genetic distinctiveness $(p=5.2 \%)$ between them and both were found to be most closely related to their putative sister species $M$. heymonsi ( $p=7.0$ $8.7 \%$ ). Genetic differentiation among the examined samples of $M$. pineticola $\mathrm{s}$. str. and the second lineage of ' $M$. cf. pineticola' from Bidoup-Nui Ba National Park was minimal (uncorrected within-group p-distance $0.1 \%$ and $0.4 \%$, respectively) (Table 2). 


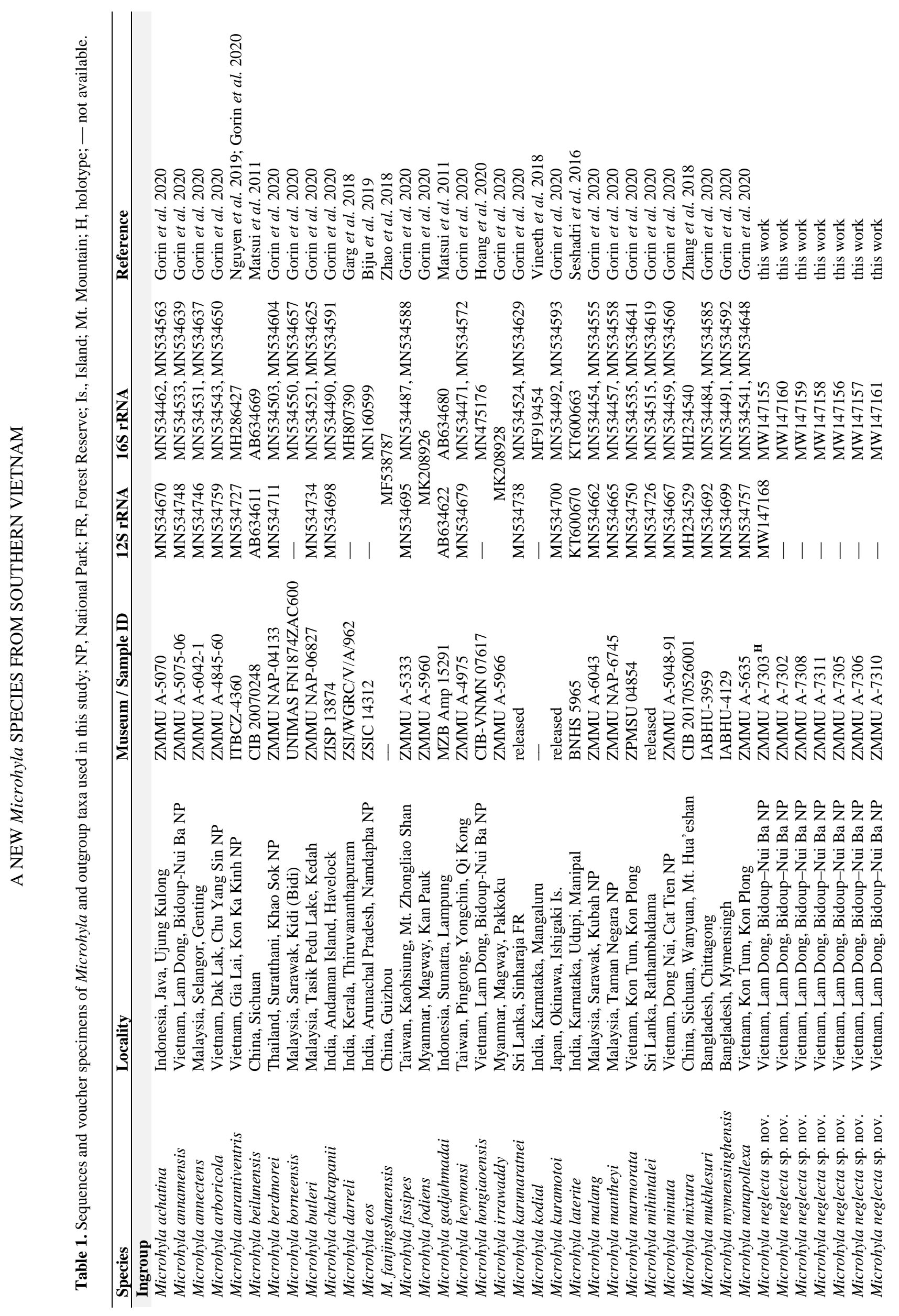




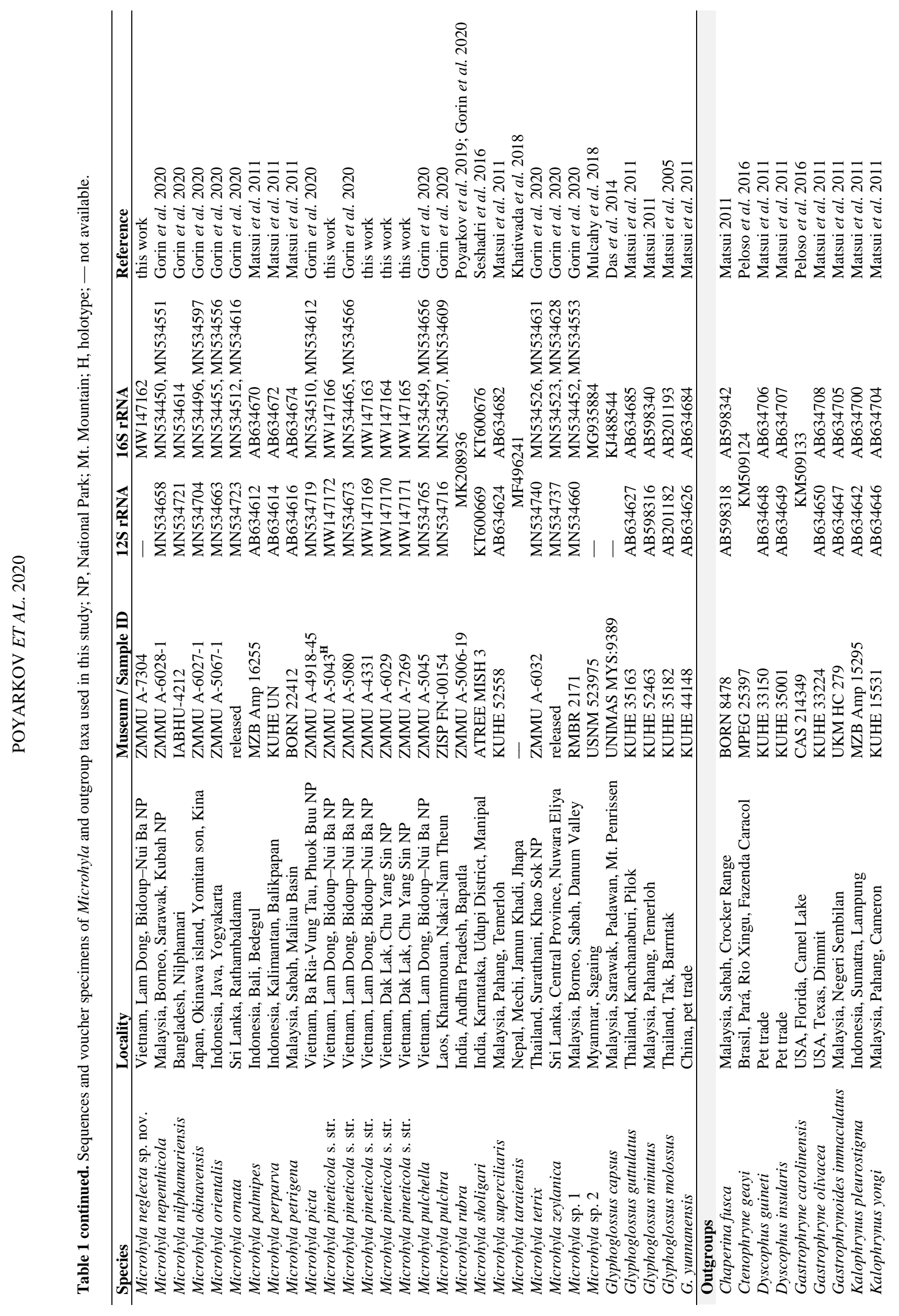



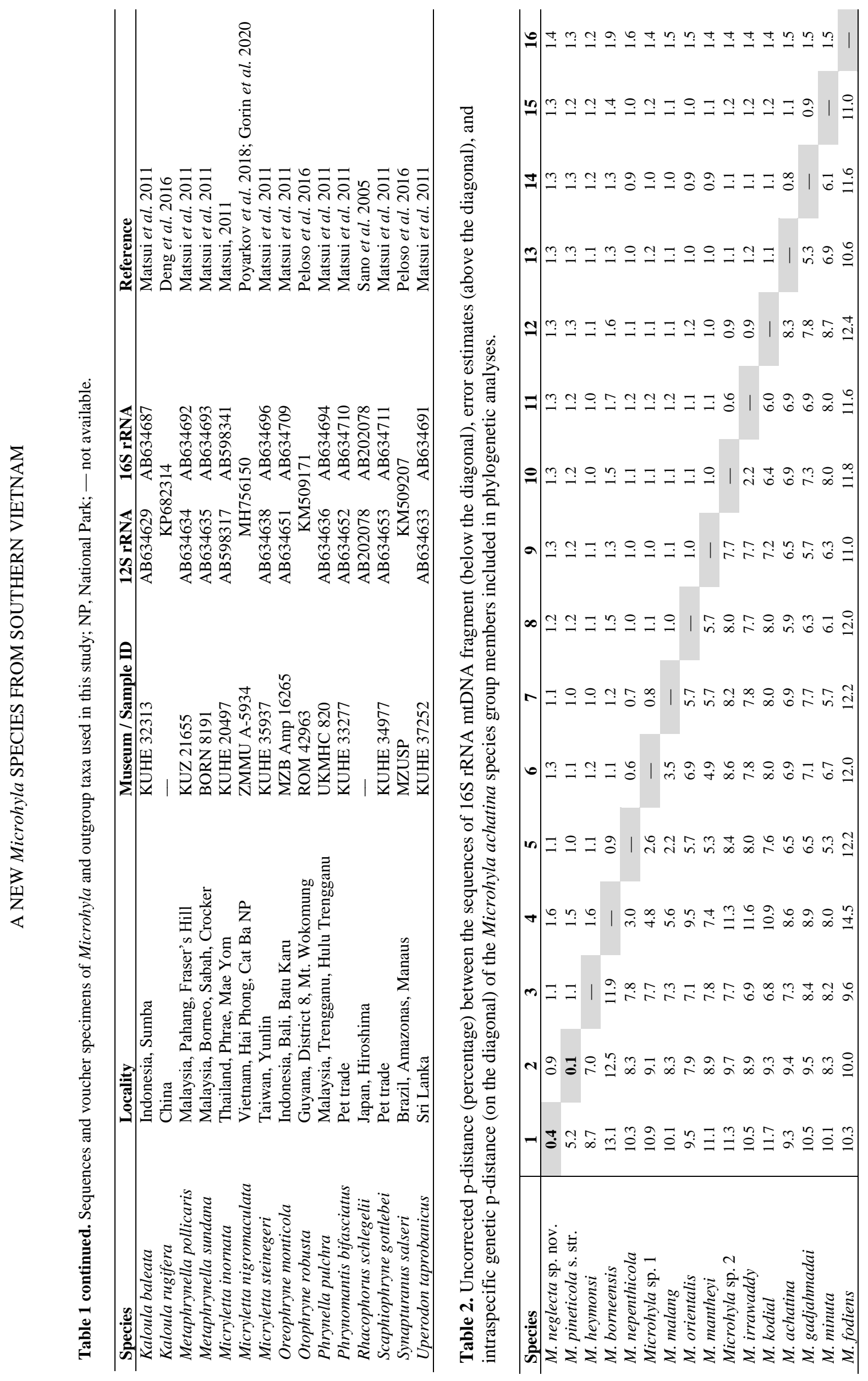


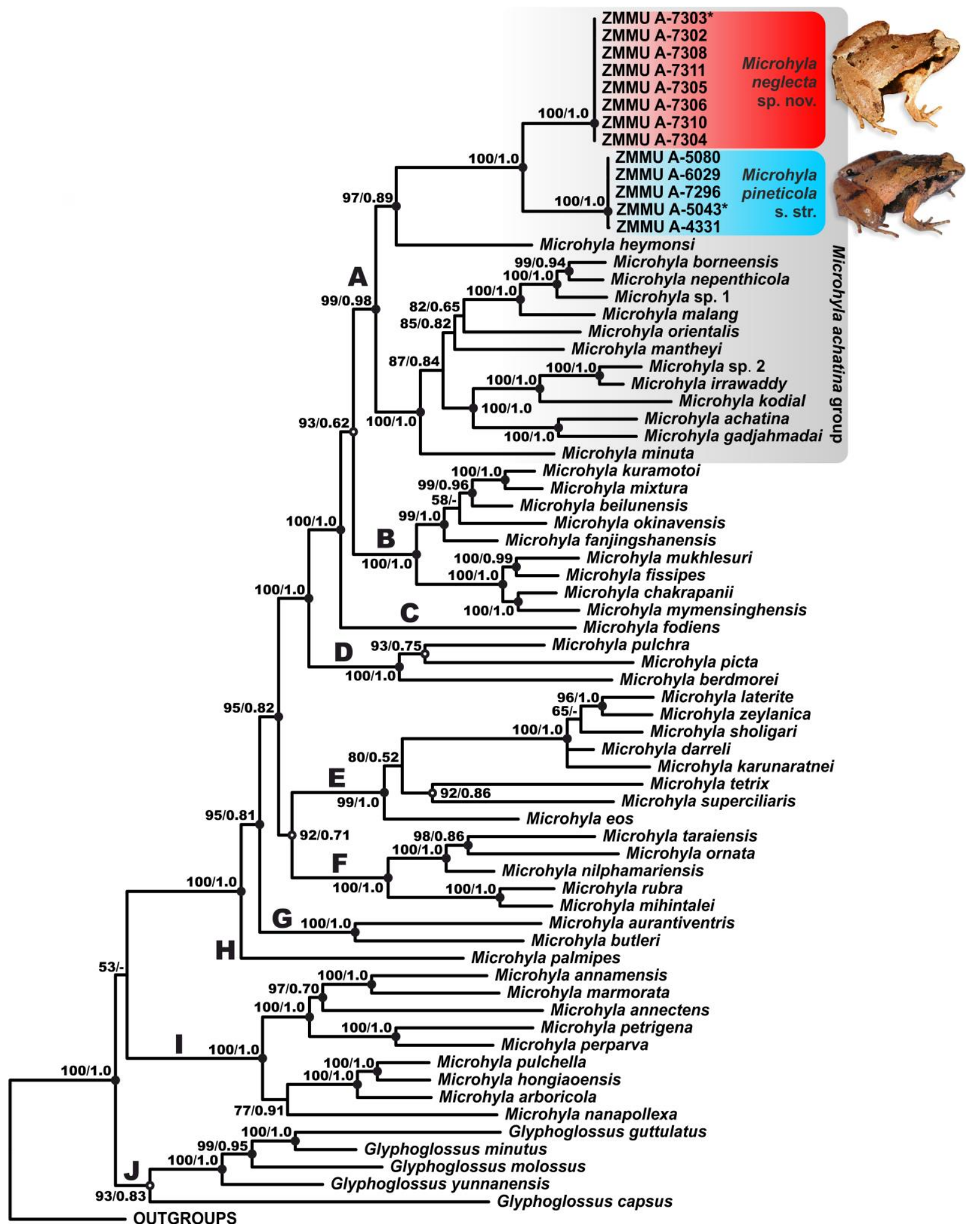

Figure 2. Maximum Likelihood tree of Microhyla derived from the analysis of $2399 \mathrm{bp}$ of alignment including $12 \mathrm{~S}$ rRNA, tRNA-Val and 16S rRNA gene fragments. For voucher specimen information and GenBank accession numbers see Table 1. Red and blue colours denote the new species and M. pineticola sensu stricto respectively, holotypes denoted with asterisks (*); grey denotes $M$. achatina species group members. Numbers at tree nodes correspond to UFBS/PP support values, respectively; well-supported nodes are marked with solid circle, moderate-support is indicated with empty circle, no circle means no-support; outgroup taxa are not shown; (C) Photos: Nikolay A. Poyarkov. 


\section{Systematics}

Our molecular analyses of the type series of Microhyla pineticola and additional specimens, have demonstrated that specimens used in the original description actually belong to two sympatric mtDNA lineages. The specimens used in the $M$. pineticola description were collected in 2009, 2010 and 2011 in three locations within the Da Nhim River Valley, in the vicinity of Giang Ly Ranger Station of the Bidoup-Nui Ba National Park (ca. 2-4 km between the localities). The members of both lineages were sympatric.

Our mtDNA-based genealogy suggests that the two mtDNA lineages of ' $M$. pineticola' are sister lineages (Fig. 2). The level of divergence in $16 \mathrm{~S}$ rRNA gene between these lineages is larger than would be expected within a single species $(p=5.2 \%)$. This value is much greater than the formal threshold of $p=3.0 \%$, widely used as an indicator of species-level status in the surveys of anuran biodiversity (Vences et al. 2005a, 2005b; Vieites et al. 2009), and also exceeds minimal interspecific distances in the $M$. achatina species group (Table 2), and among Microhyla species in general (see Gorin et al. 2020).

Though the members of the two sympatric mtDNA-lineages of ' $M$. pineticola' are superficially similar in overall body habitus and have a variable dorsal pattern, a thorough reexamination of the material has revealed a number of stable differences in colouration, pattern, and body morphology (see Comparisons). These results were concordant with the observed genetic divergence and allowed us to readily distinguish the specimens belonging to the two different mtDNA lineages. Overall, the integrative taxonomic analyses strongly support our hypothesis that the original description of $M$. pineticola was based on the type series which included the members of two sister species of Microhyla, different both morphologically and genetically, and which were unnoticed by Poyarkov et al. (2014).

In the present paper the type series of $M$. pineticola is formally split in accordance with the International Code of Zoological Nomenclature (ICZN 1999); the former paratypes of $M$. pineticola (eleven specimens from ZMMU A-4331, three specimens from ZMMU A-5080) are below designated as holotype (new collection ID ZMMU A-7303) and paratypes (new collection IDs ZMMU A7297-7302, ZMMU A-7304-7310) of the new species we describe herein. Below, we provide a detailed description and a revised diagnosis for $M$. pineticola sensu stricto, and describe the second lineage of ' $M$. cf. pineticola' from Bidoup-Nui Ba National Park as a new species.

Microhylide Günther, 1858

Microhyla Tschudi, 1838

\section{Microhyla pineticola}

Poyarkov, Vassilieva, Orlov et al., 2014

Pine narrow-mouth frog

(Figs. 3, 4F; Tables 3, 4)

Holotype. Adult female, ZMMU A-5043 (field number NAP-01032), collected from Mt. Bidoup $\left(12^{\circ} 957.24 \mathrm{~N}, 108^{\circ} 3944.28 \mathrm{E}\right.$; alt. $1,800 \mathrm{~m}$ a.s.l.), Bidoup-Nui Ba National Park, Da Nhim River Valley, Da Chais Commune, Lac Duong District, Lam Dong Province, Vietnam, by N.A. Poyarkov on 01 May 2009 (see Poyarkov et al. 2014: 100).

Paratypes $(n=3)$ : adult males, ZMMU A4331 (field number NAP-00414) and ZMMU A4331 (field number NAP-00451); adult female, ZMMU A-5080 (field number NAP-01750); data same as that for the holotype (only those paratypes which proved to be conspecific to ZMMU A-5043 are listed here).

Other materials examined ( $n=2)$ : adult male, ZMMU A-6029 (field number ABV00579), collected from Chu Yang Sin National Park $\left(12.413029^{\circ} \mathrm{N}, 108.367939^{\circ} \mathrm{E}\right.$; alt. 1,100 $\mathrm{m}$ a.s.1.), Dak Lak Province, Vietnam, by N.A. Poyarkov and A.B. Vassilieva on 23 May 2014; adult female, ZMMU A-7296 (field number ABV-00571), collected from Chu Yang Sin National Park $\left(12.418742^{\circ} \mathrm{N}, 108.364608^{\circ} \mathrm{E}\right.$; alt. 970 m a.s.1.), Dak Lak Province, Vietnam, by N.A. Poyarkov on 22 May 2014.

Revised diagnosis: Microhyla pineticola is diagnosed by a combination of the following morphological attributes: body stocky, triangular, body size small (SVL 17.4-18.6 mm in males and $20.0-22.3 \mathrm{~mm}$ in females); dorsum feebly granular with small tubercles; head triangular, snout rounded in lateral profile (Fig. 4F); finger I short, less than one-half the length of finger II; tips of three outer fingers weakly dilated, forming weak discs, with a dorsal, median, longitudinal groove; tips of all toes distinctly dilated into discs, dorsally with a weak median longitudinal groove producing the appearance of two scutes; expanded toe discs less than twice 


\section{Plate 46}

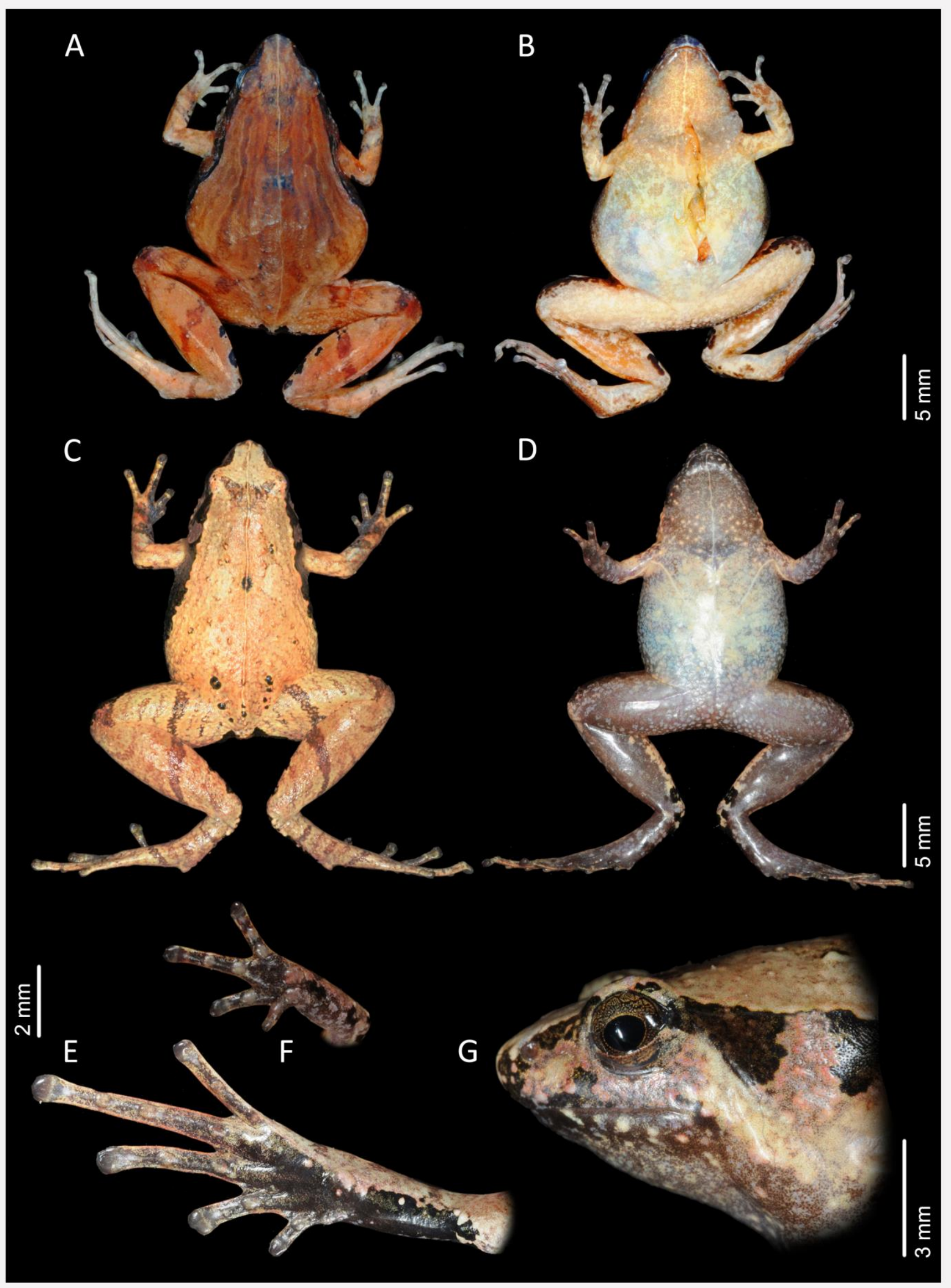

Figure 3. Microhyla pineticola (A) dorsal view and (B) ventral view of the holotype (preserved), adult female, ZMMU A-5043 from Bidoup-Nui Ba NP, Lam Dong Province, Vietnam; (C) dorsal view, (D) ventral view, (E) plantar view of left foot, (F) volar view of left hand, and (G) lateral view of the head of an adult female (in life), ZMMU A-7296, from Chu Yang Sin NP, Dak Lak Province, Vietnam. C Photos Nikolay A. Poyarkov. 
the width of phalanges; metacarpal tubercles two, both prominent and rounded; tibiotarsal articulation at straightened limb reaching beyond eye but not reaching snout tip; toe webbing basal, formula: I 1 1/2-21/2 II 13/4-3 III 23/4-33/4 IV 4-21/2 V; both inner and outer metatarsal tubercles present; upper eyelid without supraciliary spines; canthus rostralis with dark lines, top of snout welldifferentiated in colour from the brown interorbital bar, which bears a dark spot; dark stripe running from the posterior edge of eye along the supratympanic fold, interrupted above the axilla (Figs. 3G, 4F), and continues to groin as a dark lateral stripe, clearly separating darker flanks and lighter dorsum; an indistinct beige stripe extending from posterior margin of eye to axilla; the axillary region and upper lips bearing numerous bluish-white speckles; light-coloured thin, vertebral stripe present; a small, dark, rounded, middorsal spot, divided by a lightcoloured vertebral stripe; dorsal markings formed by dark-brownish lines parallel to vertebral and dorsolateral stripes, narrowly outlined in beige, forming a pattern resembling the grain of pinewood (Figs. 3A-B); chin darkgreyish with orange speckles and a thin lightcoloured medial stripe continuing to chest and belly (Figs. 3B,D); two white lines extend along the ventral surfaces of forelimbs reach the chest and meet on the midline of the belly; belly purplish-grey with indistinct whitish mottling.

Description of holotype. See Poyarkov et al. (2014). Measurements and morphological characters of the holotype and paratype series of this species are given in Table 3. The brief tadpole description presented by Poyarkov et al. (2014: 104-105, Fig. 13) may actually correspond to the larvae of the new species.

Distribution. To date known at elevations from 970 m a.s.l. in Chu Yang Sin National Park (Dak Lak Province) to $1800 \mathrm{~m}$ a.s.l. in BidoupNui Ba National Park (Lam Dong Province). This species seems to be restricted to polydominant evergreen montane forests with a predominance of Pinus krempfii Lecomte (Family Pinaceae), Lithocarpus sp., Castanopsis sp., and Quercus sp. (all Family Fagaceae); and dry monodominant pine forests formed mostly by P. kesiya Royle ex Gordon (Family Pinaceae) on the Langbian Plateau (see Poyarkov et al. 2014). Based on known distribution, habitat and elevation preferences, Microhyla pineticola is likely endemic to the Langbian Plateau, southern Vietnam (Fig. 1).
Microhyla neglecta sp. nov. [urn:Isid:zoobank.org:act:22E3B2D0-A6BB-45C7-BA7A87ADF2B17E9E]

(Figs. 4A-E; Tables 3, 4)

Microhyla "sp. 1" — Poyarkov [Paiarkov] \& Vassilieva 2011: Fig. 5.8.

Microhyla pineticola - Poyarkov et al. 2014 [partim]

Holotype. Adult male, ZMMU A-7303 (field number NAP-00553, formerly part of ZMMU A-4331 and a member of $M$. pineticola type series), collected from Da Nhim River Valley $\left(12.170838^{\circ} \mathrm{N}, 108.697765^{\circ} \mathrm{E}\right.$; alt. $1,500 \mathrm{~m}$ a.s.l.), Bidoup-Nui Ba National Park, Lam Dong Province, Vietnam by N.A. Poyarkov and A.B. Vassilieva on 26 June 2010.

Paratypes ( $\boldsymbol{n = 1 4 ) :}$ Six adult males, the former members of ZMMU A-4331 and members of $M$. pineticola type series with the following new collection numbers: ZMMU A7297 (field number NAP-00413), ZMMU A7298 (field number NAP-00415), ZMMU A7299 (field number NAP-00416), ZMMU A7300 (field number NAP-00417), and ZMMU A-7301 (field number NAP-00523), collected from Da Nhim River Valley $\left(12.180525^{\circ} \mathrm{N}\right.$, $108.681983^{\circ} \mathrm{E}$; alt. $1,450 \mathrm{~m}$ a.s.l.), Bidoup-Nui Ba National Park, Lam Dong Province, Vietnam by N.A. Poyarkov on 5 May 2009; ZMMU A7302 (field number NAP-00552), collected from $\mathrm{Da}$ Nhim River Valley $\left(12.170838^{\circ} \mathrm{N}\right.$, $108.697765^{\circ} \mathrm{E}$; alt. $1,500 \mathrm{~m}$ a.s.l.), Bidoup-Nui Ba National Park, Lam Dong Province, Vietnam, by N.A. Poyarkov and A.B. Vassilieva collected on 26 June 2010. Three adult males, the former members of ZMMU A-5080 with the following new collection numbers: ZMMU A-7304 (field number NAP-01800), and ZMMU A-7305-7306 (field numbers NAP-01884-01885) collected from Giang Ly ranger station $\left(12.185416^{\circ} \mathrm{N}\right.$, $108.689419^{\circ} \mathrm{E}$; alt. $1,480 \mathrm{~m}$ a.s.l.), Bidoup-Nui Ba National Park, Lam Dong Province, Vietnam by N.A. Poyarkov, A.B. Vassilieva and E.A. Galoyan on 07 July 2011. Four adult females, the former members of ZMMU A-4331 with the following new collection numbers: ZMMU A7307 (field number NAP-09900) collected from the northern slope of Mt. Bidoup $\left(12.116070^{\circ} \mathrm{N}\right.$, $108.660232^{\circ} \mathrm{E}$; alt. $1,800 \mathrm{~m}$ a.s.l.), Bidoup-Nui Ba National Park, Lam Dong Province, Vietnam by N.A. Poyarkov on 9 May 2009; ZMMU A7308-7309 (field numbers NAP-00418-00419) collected from Da Nhim River Valley $\left(12.180525^{\circ} \mathrm{N}, 108.681983^{\circ} \mathrm{E}\right.$; alt. $1,450 \mathrm{~m}$ 
a.s.1.), Bidoup-Nui Ba National Park, Lam Dong Province, Vietnam by N.A. Poyarkov on 5 May 2009; and ZMMU A-7310 (field number NAP01422) collected from Giang Ly ranger station $\left(12.185416^{\circ} \mathrm{N}, 108.689419^{\circ} \mathrm{E}\right.$; alt. $1,480 \mathrm{~m}$ a.s.1.), Bidoup-Nui Ba National Park, Lam Dong Province, Vietnam by N.A. Poyarkov and A.B. Vassilieva on 26 June 2010.

Diagnosis: The new species is allocated to the genus Microhyla Tschudi, 1838 based on the following combination of diagnostic characters (Parker 1934; Poyarkov et al. 2014, 2019a, 2020b): small body size; head comparatively narrow; eyes small with circular pupil; spinelike projection of skin at heel and elbow absent; maxillary and vomerine teeth absent; snout less than twice the diameter of the eye; tongue obovate, entire, and free posteriorly; webbing on fingers absent; webbing on toes basal; palmar tubercles distinct; inner and outer metatarsal tubercles prominent; supratympanic fold present; tympanum hidden under the skin.

Microhyla neglecta sp. nov. is allocated to the Microhyla achatina species group (see Garg et al. 2018; Gorin et al. 2020) and is diagnosed from all other congeners by the following combination of morphological characters: body moderately slender, small, male SVL 17.2-19.5 $\mathrm{mm}$ (males), 17.8-23.0 mm (females); dorsum smooth with evenly scattered small flat, tubercles; snout sharply acuminate in lateral profile, nostrils on the lateral sides of snout; finger I longer than one-half the length of finger II; tips of three outer fingers weakly dilated forming weak discs, with median, dorsal, longitudinal grooves; tips of all toes distinctly dilated into discs, with median, dorsal longitudinal grooves; expanded toe discs ca. two times wider than width of penultimate phalanges; metacarpal tubercles two, outer round, inner tubercle oval and prominent; tibiotarsal articulation of a straightened limb reaching well beyond snout; toe webbing basal, formula: I 11/221/2 II 13/4-3 III 23/4-33/4 IV 33/4-21/2 V; metatarsal tubercles two, prominent, inner elongate, outer round; upper eyelid lacking supraciliary spines or tubercles; a dark line extends along canthus rostralis; dorsal surface of snout light-grey, welldifferentiated in colour from the dark-brown interorbital bar, which bears an 8-shaped, dark, medial blotch; a narrow, continuous, black stripe running from the posterior margin of the eye, along the supratympanic fold, transforming into a dark dorsolateral stripe reaching the groin; a distinct, narrow, cream-white stripe extending from the posterior margin of the eye to the axilla; the axillary region and upper lips lack bluishwhite speckles; dorsal pattern formed by a weak light-coloured, thin, vertebral stripe; small, dark, middorsal oval marking; a light-brown chevronshaped marking or "teddy-bear" edged with beige; the lateral sides of dorsum may have indistinct, thin, brownish lines forming nested reverse V-shaped figures; centre of chin grey, sides dark-brown to black, with a thin, lightcoloured medial stripe not reaching the chest; belly yellowish with indistinct greyish marbling laterally.

Description of holotype: A small-sized, SVL $18.1 \mathrm{~mm}$, adult male specimen in a generally good state of preservation (slightly dehydrated); body habitus moderately slender; head comparatively large, almost as long as wide (HL/HW 1.01); snout truncate in dorsal view, sharply acuminate in lateral profile, slightly protruding beyond lower jaw, longer than eye diameter (EL/SL 0.86); eye rounded, comparatively small, slightly protuberant in dorsal view and not protruding in lateral view, pupil horizontal; dorsal surface of head slightly convex, canthus rostralis sharp; loreal region distinctly concave; nostrils rounded, placed more on the sides of the snout, located closer to the tip of snout than to the eye; tympanum hidden under skin of temporal region; supratympanic fold weak, becoming indistinct above the axilla; maxillary and vomerine teeth absent; vocal sac single, subgular; tongue obovate, entire, and free posteriorly, lacking papillae.

Forelimbs short, ca. one-third of hindlimb length (FLL/HLL 0.34); hand short (HAL/LAL 0.55; HAL/FLL 0.44); fingers comparatively thin, rounded in cross-section, first finger slightly longer than half of second finger length (1FL/2FL 0.53); relative length of fingers: $\mathrm{I}<\mathrm{IV}<\mathrm{II}<\mathrm{III}$. Webbing absent between all fingers; dermal fringes absent; tips of all fingers rounded, tip of finger I not enlarged, tips of fingers II-IV notably widened forming discs, with median, dorsal, longitudinal grooves and dorso-terminal grooves; third finger disc largest; subarticular tubercles on volar surface of fingers barely distinct, flattened, subarticular tubercle formula: 1:1:2:2; nuptial pad absent; two metacarpal (palmar) tubercles, both distinct, inner tubercle round, outer tubercle elongate, slightly larger than inner one (IPTL/OPTL 0.79); area between 


\section{Plate 47}

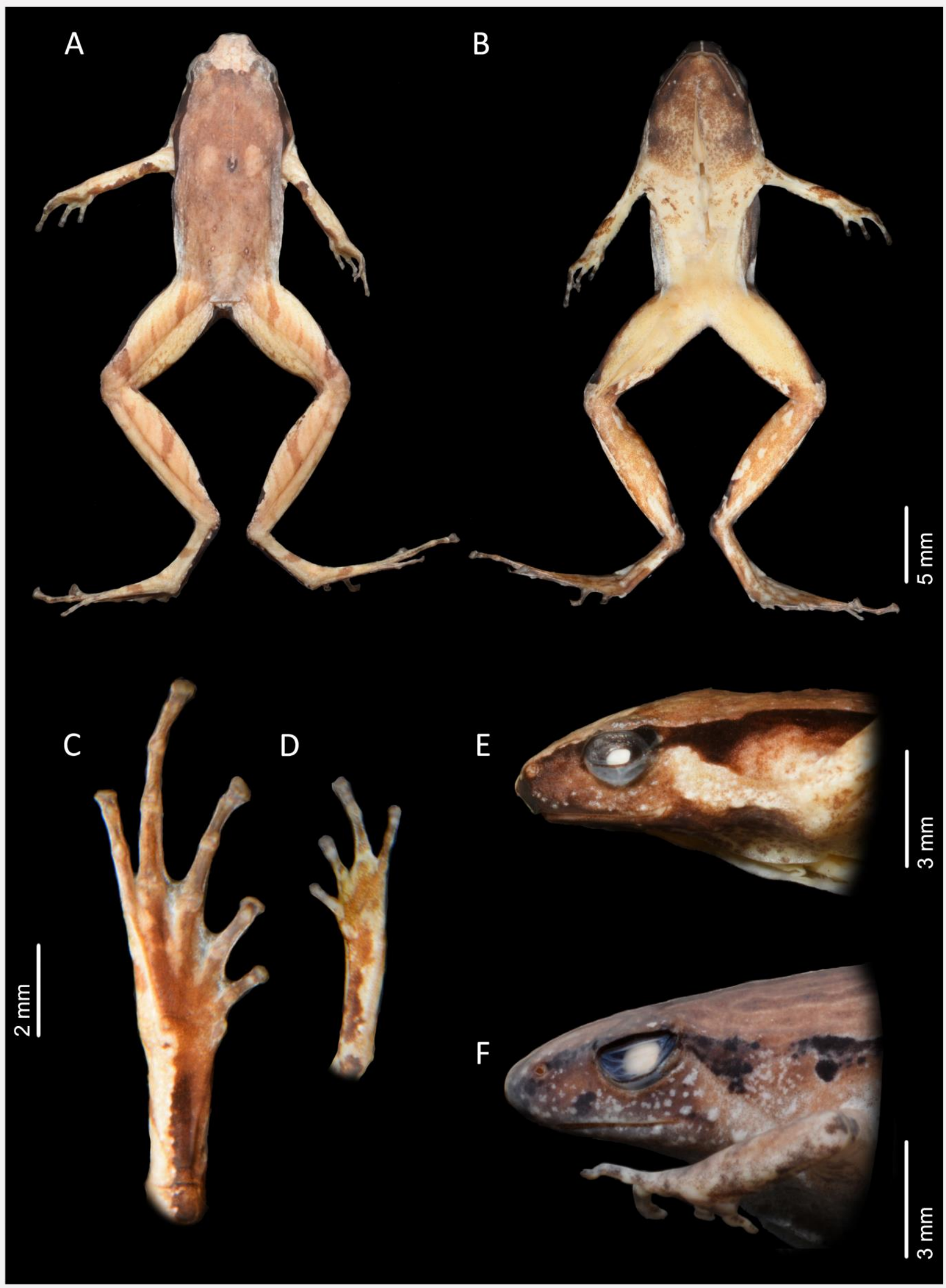

Figure 4. (A) dorsal view, (B) ventral view, (C) plantar view of right foot, (D) volar view of left hand, and (E) lateral view of the head of Microhyla neglecta sp. nov., holotype, adult male, ZMMU A-7303; and (F) lateral view of the head of M. pineticola, holotype, adult female, ZMMU A-5043. Both holotypes are from BidoupNui Ba NP, Lam Dong Province, Vietnam. C Photos Nikolay A. Poyarkov. 


\section{Plate 48}
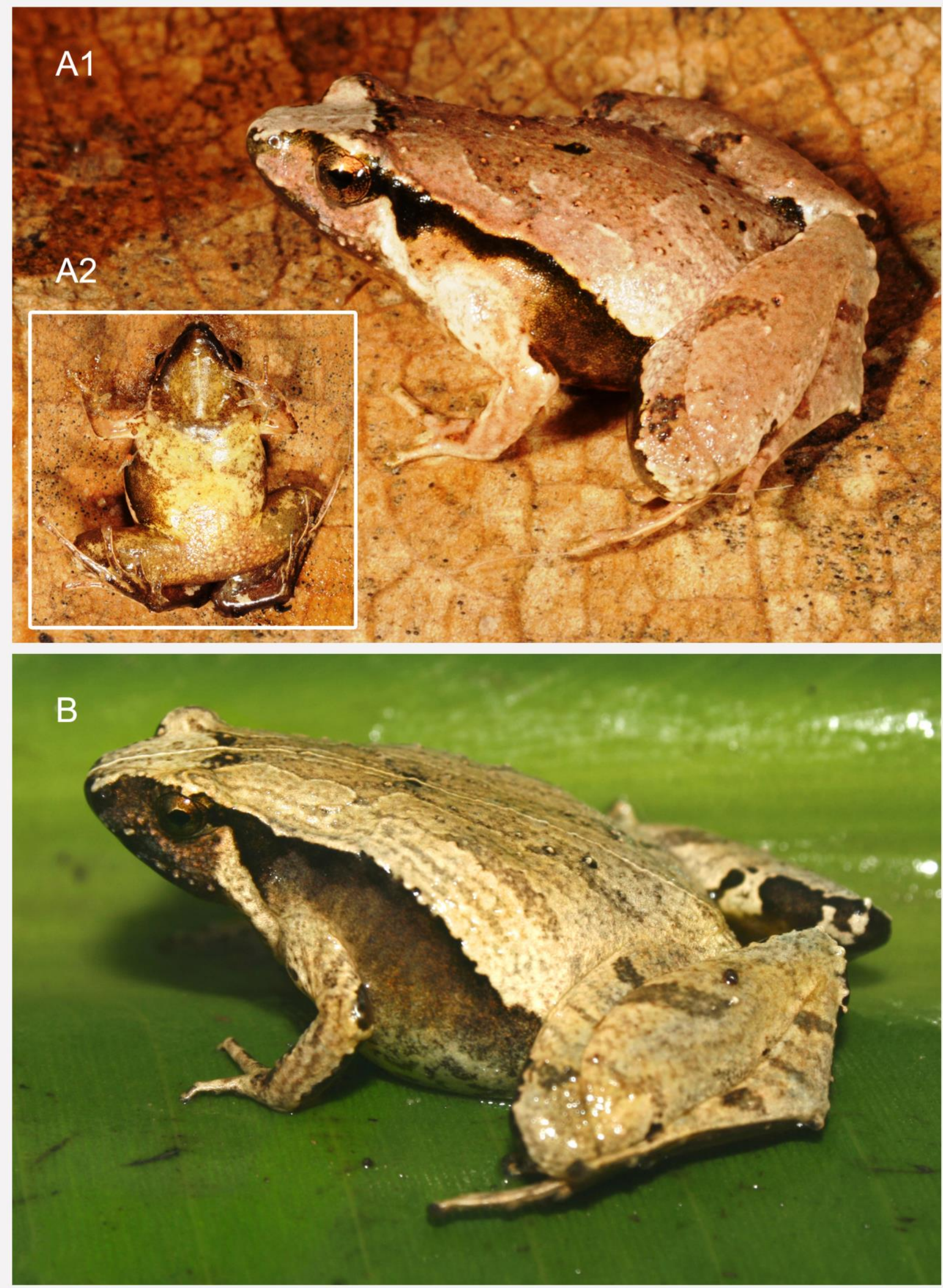

Figure 5. Microhyla neglecta sp. nov. in life (A1) dorsolateral view, (A2) ventral view of paratype, adult male, ZMMU A-7302; and (B) dorsolateral view of paratype, adult female, ZMMU A-7307. Both paratypes are from Bidoup-Nui Ba NP, Lam Dong Province, Vietnam. (C) Photos Nikolay A. Poyarkov. 
inner and outer palmar tubercles flat and lacking medial or supernumerary palmar tubercles.

Hindlimbs comparatively long, tibia length much longer than half of snout-vent length (TL/SVL 0.61), hindlimb length over 1.5 times longer than snout-vent length (HLL/SVL 1.80); tibiotarsal articulation of adpressed limb reaching well beyond snout (checked prior to preservation); tibia slightly longer than foot (FL/TL 0.98); relative toe lengths: $\mathrm{I}<\mathrm{II}<\mathrm{V}<\mathrm{III}<\mathrm{IV}$; tarsal fold on inner surface of tarsus absent; tips of all toes rounded and widened, forming broad, terminal discs; all toe discs having distinct dorso-terminal groves; discs on toes II-V having distinct median, distal, dorso-longitudinal grooves not reaching over one-half of disc length and producing the appearance of two scutes; toes long, thin, slightly flattened in cross-section; toe webbing basal, formula: I 1 1/2-21/2 II 13/4-3 III 23/4$33 / 4$ IV $33 / 4-2 \frac{1}{2} \mathrm{~V}$; toe subarticular tubercles distinct, round, slightly protruding, subarticular tubercle formula: 1:1:2:3:2; two metatarsal tubercles: inner metatarsal tubercle elongate, oval, slightly prominent; outer metatarsal tubercle small, round, shorter than the inner tubercle (OMTL/IMTL 0.74), slightly protruding.

Skin on dorsal surface of head and body smooth with small, flat tubercles irregularly scattered along the medial part of dorsum; supratympanic fold slightly swollen, becoming indistinct posteriorly at level of the axilla; upper eyelid without supraciliary spines or tubercles; lateral head and body smooth, forelimbs dorsally smooth, hindlimbs with few small, flat, dorsal tubercles; ventral surfaces of body and limbs smooth, ventral surfaces of thighs with numerous flat, glandular pustules, cloacal region smooth with few tubercles. Cloacal opening unmodified, directed posteriorly, at the lower level of thighs.

Colouration of holotype. In life, dorsally light-brown, with a distinct slightly darker brownish "teddy-bear"-shaped pattern (sensu Rakotoarison et al. 2017) edged with beige. Anterior parts of head and snout light-grey above, well-differentiated in colour from the darker dorsum. A distinct dark-brown interorbital transverse bar between most medial edges of upper eyelids, extending anterolaterally, covering almost all the posterior two thirds of eyelid; an 8-shaped, medial, dark blotch within the interorbital bar. A weak, thin, light-coloured vertebral stripe runs from the tip of the snout to the vent. A small, elongate, U-shaped, black spot at middorsum. Small tubercles on dorsum edged with brown; two series of three, black sacral spots on each side of body. Dorsolateral surfaces of trunk and upper arm light-brown with indistinct greyish pattern; forelimbs lacking darker dorsal cross-bars, hindlimbs with a single, brown, dorsal cross-bar on proximal part of thighs and middle part of shanks; fingers and toes light-brown above with indistinct, brownish cross-bars. Lateral head brownish, a dark-brown lateral stripe running from tip of snout to nostril, and curving along the edge of the canthus rostralis towards the anterior margin of the eye; upper and lower lips dark-brown with a few light-coloured speckles. A black stripe extends from the posterior margin of the eye along the supratympanic fold to above the axilla along a dorsolateral line reaching the groin and separating the light-brown colouration of dorsum from the dark-brown colour of flanks; the stripe fades ventrally towards the groin. A distinct, narrow, cream-white stripe extends from the posterior margin of the eye to the axilla. Centre of chin grey, sides dark-brown to black with a thin, light-coloured medial stripe not reaching the chest; chest and belly yellowish with indistinct greyish marbling laterally; limbs greyish-pink below with creamy or yellowish irregularly shaped blotches. Iris bronze with dense black dusting at the anterior and posterior edges; pupil horizontal, black, outlined with a golden circle.

In preservative, after ten years of preservation in ethanol, the colours have significantly faded (Fig. 4). The ground colouration of dorsum faded to greyish-brown, black spots and stripes fade to dark-brown, colouration of iris and the yellowish tint of ventral colouration faded completely. However, the overall pattern on dorsum, flanks, and venter remained unchanged.

Variation. Morphometric variation of the type series is presented in Table 3. Paratypes are generally similar to the holotype in body proportions and colouration, with only slight variation is observed in shape of the dorsal pattern. All specimens have a continuous black stripe running from the posterior margin of the eye to the groin. Males (SVL 17.2-19.5 mm, mean $18.3 \pm 0.8 \mathrm{~mm} ; n=10$ ) were slightly smaller than females (SVL 17.8-23.0 mm, mean $19.5 \pm 2.1 \mathrm{~mm} ; n=5)$. Colouration also differed little between the sexes. In males, the dorsal pattern is generally represented by indistinct 
'teddy-bear' or chevron-shaped brownish markings with weak, beige edging (Fig. 5A), while in females, like in ZMMU A-7307 (see Fig. 5B), the lateral body has indistinct, thin, brownish lines forming nested reverse $\mathrm{V}$-shaped figures resembling that of $M$. pineticola. Female ZMMU A-7307 was swollen with yellowishwhite eggs with a dark-brown animation pole, ca. $1.1-1.2 \mathrm{~mm}$ in diameter $(n=10)$.

Etymology. Specific epithet "neglecta" is a Latin adjective in nominative singular, feminine form of "neglectus", Latin for "having been overlooked". The name is given in reference to the complicated taxonomic history of the new species, which remained unnoticed until recently and was even included in the type series of its sister species $M$. pineticola. We recommend "Neglected narrow-mouth frog" as the common English name, "Nezamechennyi Uzkorot" as the name in Russian, and "Nhái bầu quên lãng" in Vietnamese.

Comparison. The differences of the new species from all other congeners are summarized in Table 4. In general morphology, Microhyla neglecta sp. nov. superficially most resembles its sister species $M$. pineticola s. str., however the new species can be readily distinguished from the latter by having the following suite of morphological characters: (1) a moderately slender body (Fig. 4A) ( $v s$ stocky, triangular, see Figs. 3A,C); (2) a thick continuous black stripe running from the posterior edge of eye to the groin (see Fig. 4E, Fig. 5A1) ( $v s$ thin and interrupts above the axilla, see Fig. 3G, Fig. 4F); (3) a yellowish belly with indistinct greyish marbling laterally (see Fig. 4B, Fig. 5A2) (vs purplish-grey with indistinct whitish mottling, Fig. 3B,D); (4) medially grey throat laterally dark brown to black, with a thin white medial line running from chin upto the posterior edge of throat (Fig. 4B, Fig. 5A2) (vs dark-greyish laterally orange speckles, with a thin light-colour medial line running from chin upto the chest and belly, and also connects to the two white lines continuing to the ventral surface of forelimbs, see Fig. 3D); (5) a distinct thin cream-white stripe from posterior eye to axilla and uniform lips and axilla (Fig. 4E) ( $v s$ an indistinct beige stripe, and the upper lips and axilla with numerous bluish-white speckles, see Fig. 3G, Fig. 4F); (6) first finger longer than one half of the second finger ( $v s$ shorter); (7) an oval shaped, elongated outer metacarpal tubercle (vs rounded); (8) comparatively longer hindlimbs, with a tibiotarsal articulation of straightened limb projecting well beyond snout ( $v s$ shorter than snout); (9) slightly less developed foot webbing I $1 \frac{1}{2} 2-2 \frac{1}{2}$ II $13 / 4-3$ III $23 / 4-33 / 4$ IV $33 / 4-$ $2 \frac{1}{2} \mathrm{~V} \quad$ (vs $\quad$ I $1 \frac{1}{1} 2-2^{1 / 2}$ II $13 / 4-3$ III 23/4-33/4 IV 4$2 \frac{1}{2} \mathrm{~V}$ ); and (10) sharply acuminate snout in lateral profile ( $v s$ rounded).

Based on morphological characteristics and the phylogenetic position, Microhyla neglecta sp. nov. can be assigned to the $M$. achatina species group, and its comparison to other members of this group are the most pertinent; we present it below. The new species differs from (1) $M$. achatina by having a smaller body SVL 17.2$19.5 \mathrm{~mm}$ in males and $17.8-23.0 \mathrm{~mm}$ in females ( vs $19.7-23.0 \mathrm{~mm}$ in males and $24.0-26.1 \mathrm{~mm}$ in females), first finger longer than one half of the second finger ( $v s$ shorter), a black spot on the middorsum ( $v s$ absent), a comparatively less developed foot webbing I 1 1 $2-2-2 \frac{1}{2}$ II $13 / 4-$ 3 III 23/4-33/4 IV 33/4-21/2 V (vs I 2-21/2 II 231/4 III 3-4 IV 4-3 V), and a continuous dark line above the axilla ( $v s$ interrupted); (2) from $M$. borneensis by having a larger body SVL 17.2$19.5 \mathrm{~mm}$ in males and $17.8-23.0 \mathrm{~mm}$ in females (vs $11.0-13.0 \mathrm{~mm}$ in males and $18.0-19.0 \mathrm{~mm}$ in females), a well-developed first finger ( $v s$ greatly reduced to a nub), a light vertebral line ( $v s$ absent), tibiotarsal articulation reaching well beyond snout ( $v s$ not reaching the snout); (3) from $M$. fodiens by having a moderately slender body habitus ( $v s$ stout), snout acuminate in lateral profile ( $v s$ rounded), first finger longer than one half of the second finger ( $v s$ shorter), longitudinal grooves on the dorsal surface of fingers and toes ( $v s$ absent), a light vertebral line ( $v s$ absent), and tibiotarsal articulation reaching well beyond snout ( $v s$ not reaching the eye); (4) from $M$. gadjahmadai by having a moderately slender habitus ( $v s$ stout), snout acuminate in lateral profile ( $v s$ rounded), a strong continuous dark stripe above the axilla ( $v s$ thin and interrupted), and a comparatively less developed foot webbing I 1 1/2-2 $1 / 2$ II 13/4-3 III 23/433/4 IV 33/4-21/2 V (vs I 2-21/4 II 13/4-3 III 3-4 IV 4$23 / 4 \mathrm{~V}$ ); (5) from $M$. heymonsi by having two lower metacarpal tubercles and no supernumerary tubercles on palm ( $v s$ three distinct prominent metacarpal tubercles and supernumerary tubercles), snout acuminate in lateral profile ( $v s$ obtusely pointed), tibiotarsal articulation reaching well beyond snout ( $v s$ not reaching the snout), and a comparatively less developed foot webbing I 1 1/2-21/2 II 13/43 III 23/4-33/4 IV 33/4-21/2 V (vs I 2-21/2 II 2-3 III 34 IV $4 \frac{1}{3}-3 \mathrm{~V}$ ); (6) from $M$. irrawaddy by having 
a larger body SVL $17.2-19.5 \mathrm{~mm}$ in males (vs 12.3-17.1 mm), a smooth dorsum with few small tubercles ( $v s$ granular), longitudinal grooves on the dorsal surface of fingers and toes ( $v s$ absent), supratympanic fold distinctly edged with black ( $v s$ absent), tibiotarsal articulation reaching well beyond snout ( $v s$ not reaching the snout), and a comparatively less developed foot webbing I 1 1 1/2-21/2 II 13/4-3 III 23/4-33/4 IV 33/4$21 / 2$ V (vs I 2-3 II 2-3 III 3-41/2 IV 41/2-23/4 V); (7) from $M$. kodial by having snout acuminate in lateral profile ( $v s$ rounded), canthus rostralis distinct ( $v s$ indistinct), a vertebral line ( $v s$ absent), and a lateral dark stripe from eye to groin ( $v s$ absent); (8) from M. malang by having snout acuminate in lateral profile ( $v s$ rounded), first finger longer than one half of the second finger ( $v s$ shorter), a dark continuous line above the axilla ( $v s$ interrupted), a light-colour vertebral line ( $v s$ absent), and a comparatively less developed foot webbing I 1 1 $1 \frac{2-21 / 2}{2}$ II $1 \frac{3}{4}-$ 3 III 23/4-33/4 IV 33/4-21/2 V (vs I 1-2 II 122/3 III 12/3-3 IV 3-1 V); (9) from $M$. mantheyi by having first finger longer than one half of the second finger ( $v s$ shorter), a smooth dorsum with few small tubercles ( $v s$ granular with regularly scattered pustules), a dark continuous line above the axilla ( $v s$ interrupted); (10) from $M$. minuta by having a larger body SVL $17.2-19.5 \mathrm{~mm}$ in males and 17.8-23.0 $\mathrm{mm}$ in females (vs 14.7$15.9 \mathrm{~mm}$ in males and $15.7-17.2 \mathrm{~mm}$ in females), smooth dorsum with few small tubercles ( $v s$ granular with regularly scattered pustules), a dark dorsolateral stripe (vs absent), a light-colour vertebral line ( $v s$ absent), and tibiotarsal articulation reaching well beyond snout ( $v s$ not reaching the snout); (11) from $M$. orientalis by having a larger body SVL 17.2$19.5 \mathrm{~mm}$ in males and $17.8-23.0 \mathrm{~mm}$ in females (vs $15.8-17.4 \mathrm{~mm}$ in males and $15.8-17.4 \mathrm{~mm}$ in females), first finger longer than one half of the second finger ( $v s$ shorter), tibiotarsal articulation reaching well beyond snout ( $v s$ not reaching reaching the snout), and a distinct light vertebral line ( $v s$ faint).

Distribution. To date, the new species is known exclusively from three localities within the eastern portion of the Bidoup-Nui $\mathrm{Ba}$ National Park in Lam Dong Province, southern Vietnam. Microhyla neglecta was observed at elevations from 1,450 $\mathrm{m}$ a.s.l. (in the environs of the Giang Ly ranger station) to $1,800 \mathrm{~m}$ a.s.l. (on the northern slope of Mt. Bidoup). All three known localities are located within a narrow area (approximately $20 \mathrm{~km}^{2}$ ) within the Da Nhim River Valley.

Natural history. All the Microhyla neglecta specimens were found on the ground (both during day and night) in mixed montane tropical forests with a predominance of Lithocarpus sp., Castanopsis sp., and Quercus sp. (Family Fagaceae), Pinus krempfii (Family Pinaceae), and with a dense understory comprised of Pandanus sp. (Family Pandanaceae) and various bushes and small trees.

In all localities surveyed, $M$. neglecta was recorded in sympatry with $M$. pineticola, though the specimens of the new species were usually found within mixed montane forest, while $M$. pineticola specimens were often recorded in open areas and dry monodominant pine forests comprised of Pinus kesiya. Other syntopic amphibian species were $M$. annamensis Smith, 1923; M. berdmorei (Blyth, 1856); M. pulchella Poyarkov, Vassilieva, Orlov et al., 2014; Ingerophrynus galeatus (Günther, 1864); Feihyla palpebralis (Smith, 1924); Rhacophorus calcaneus Smith, 1924; R. vampyrus Rowley, Le, Tran et al. 2010; and Polypedates megacephalus Hallowell, 1861.

The reproduction of the new species is insufficiently studied due to the earlier confusion with the sympatric and superficially similar species $M$. pineticola. Further morphological and genetic studies are required to clarify the differences in larval morphology between these two species.

Conservation status. To date, Microhyla neglecta is known only from a narrow area within Bidoup-Nui Ba National Park (Lam Dong Province), Langbian Plateau, southern Vietnam. Our intensive surveys in several other forested areas on the Langbian Plateau within Lam Dong, Khanh Hoa, and Dak Lak Provinces failed to discover new populations of $M$. neglecta. Thus the actual extent of distribution of the new species and its population trends remain unknown.

The application of the IUCN Red List criteria (2019: version 14) shows that Microhyla neglecta is restricted to an extent of occurrence (EOO) of $70-100 \mathrm{~km}^{2}$ where 15 individuals were recorded within $10 \mathrm{~km}$ distance. Given the relatively narrow distribution range and the rapid montane forest fragmentation accelerated by the high human population density within the range, we suggest $M$. neglecta to be considered a Near Threatened (NT) species. 


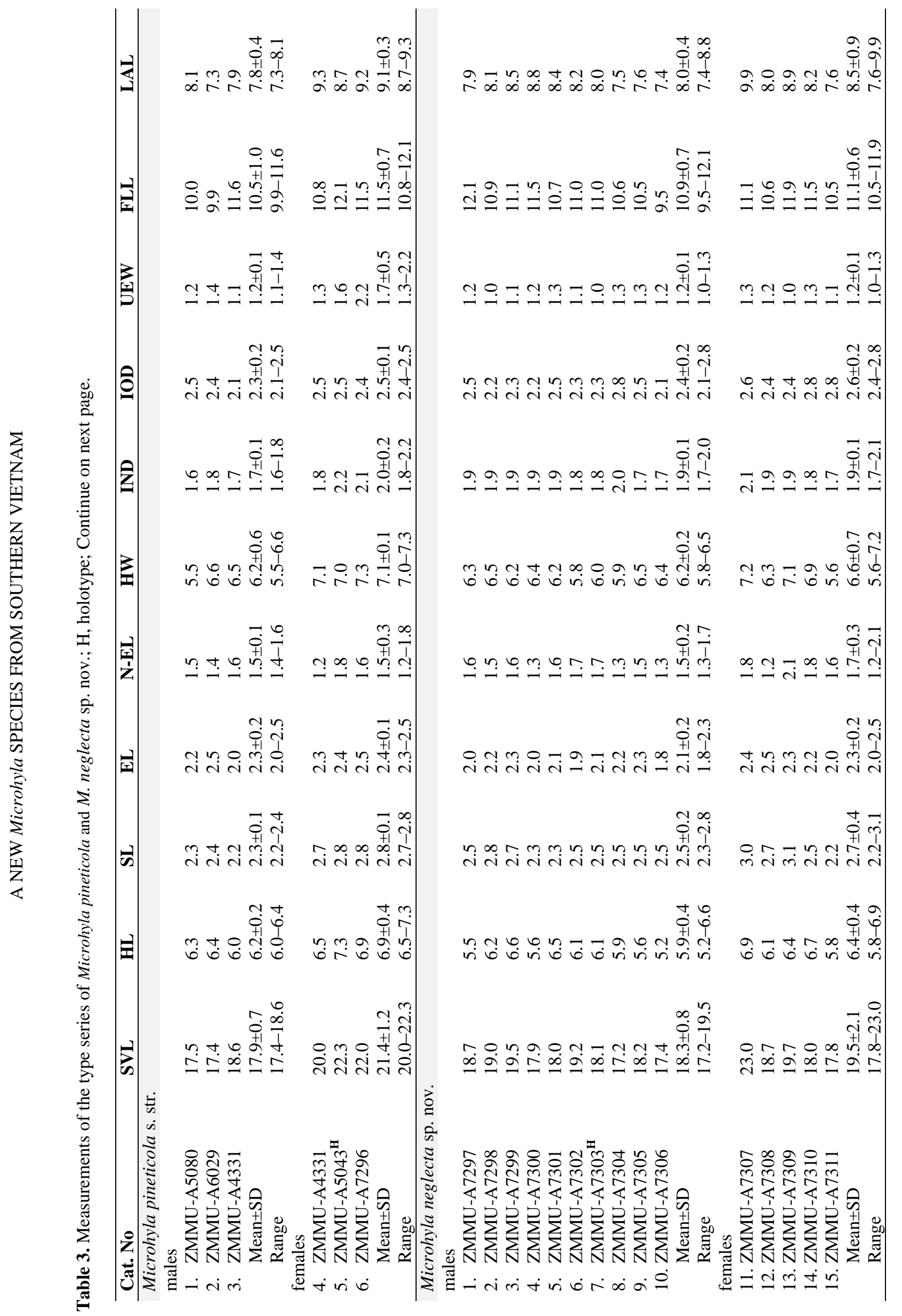


人ิ

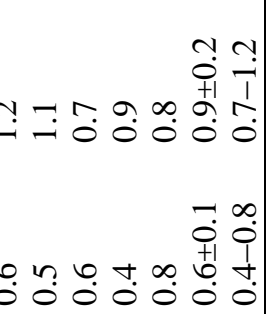

言

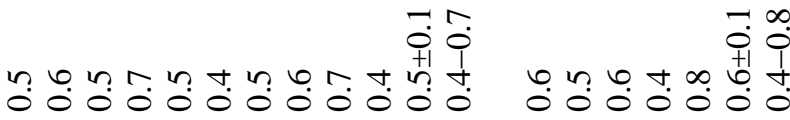

音

귘저

20

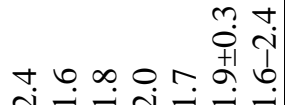

달ำ

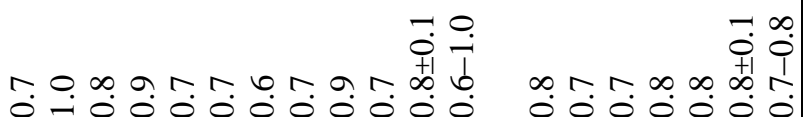

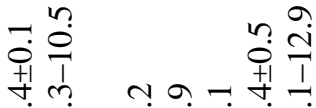

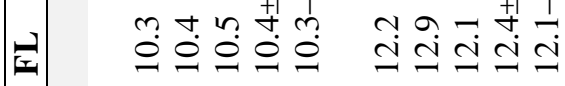

算禀

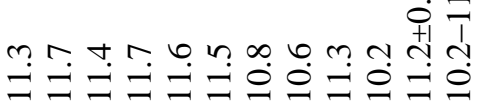

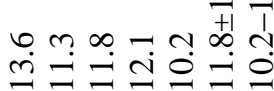

กำ

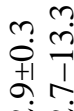

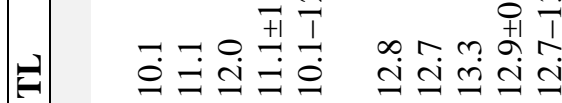

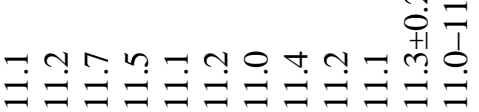

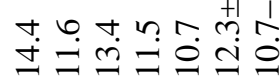

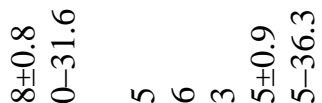

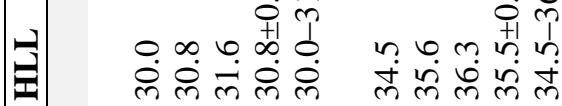

ก เ

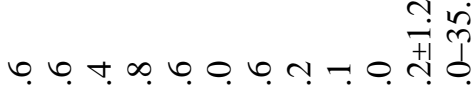

o. $\frac{1}{2}$ ก लं तैं

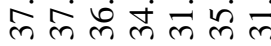

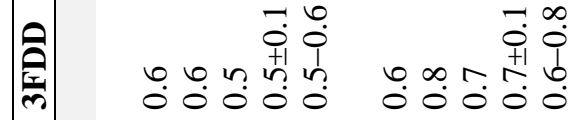

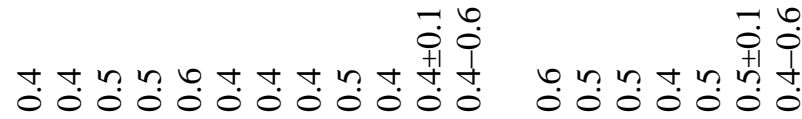

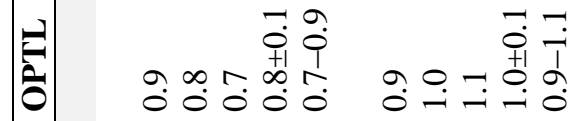

r.

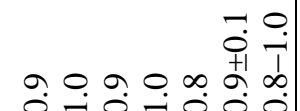

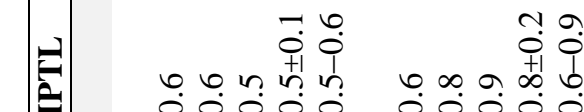

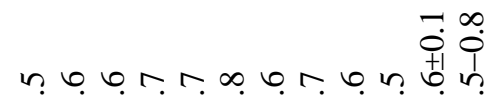
(2) ○ $\dot{0} \dot{0} \dot{0} \dot{0} \dot{0} \dot{0} \dot{0} \dot{0} 0 \dot{0}$

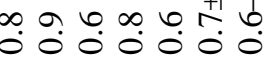

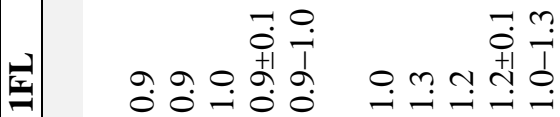

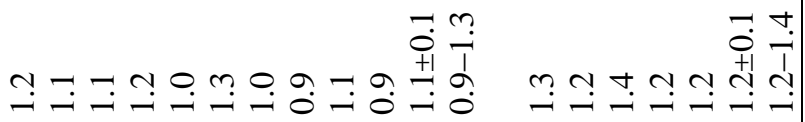

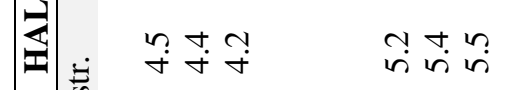

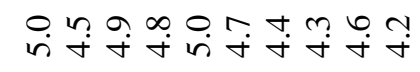

mִ

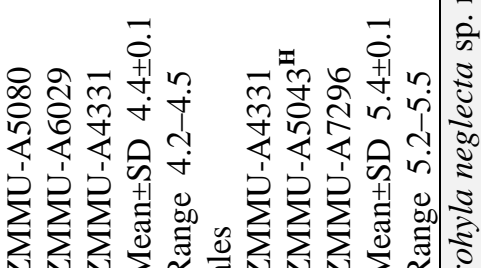

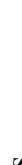

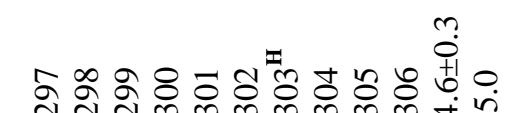

and $4 m$ men

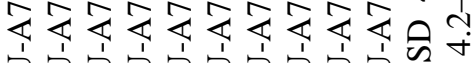

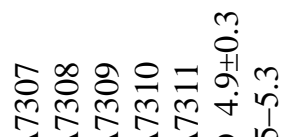

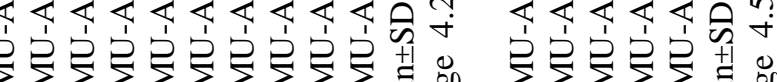

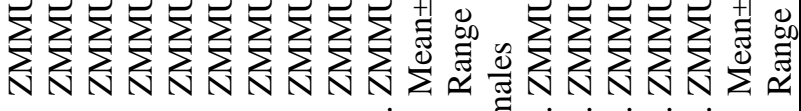

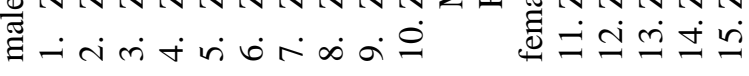


Table 4. Morphological comparison between Microhyla neglecta sp. nov with 52 currently recognized species of genus Microhyla. Members of the M. achatina species group are highlighted; ? = no data.

\begin{tabular}{|c|c|c|c|c|}
\hline Species & SVL (males) & SVL (females) & Body habit & Snout in lateral profile \\
\hline M. neglecta sp. nov. & $17.2-19.5$ & $17.8-23.0$ & Moderately slender & Acuminate \\
\hline M. achatina & $21.7-24.3$ & $20.6-28.0$ & Slender & Obtusely pointed \\
\hline M. annamensis & $15.2-19.8$ & $18.2-22.6$ & Moderately stocky & Bluntly rounded \\
\hline M. annectens & $14.4-15.6$ & $18.2-18.4$ & Slender & Rounded \\
\hline M. arboricola & $13.2-15.0$ & $15.9-17.0$ & Moderately slender & Pointed \\
\hline M. aurantiventris & $25.2-27.0$ & 30.5 & Moderately stocky & Rounded \\
\hline M. beilunensis & $19.1-23.7$ & $26.4-28.3$ & Moderately slender & Bluntly rounded \\
\hline M. berdmorei & $23.8-32.5$ & $26.2-45.6$ & Slender & Obtusely pointed \\
\hline M. borneensis & $11-13$ & $18-19$ & Stocky & Obtusely pointed \\
\hline M. butleri & $20.0-25.0$ & $21.0-26.0$ & Slender & Rounded \\
\hline M. chakrapanii & 22 & $?$ & Moderately stout & Obtusely rounded \\
\hline M. darevskii & $27.0-32.6$ & $?$ & Stocky, flattened & Rounded \\
\hline M. darreli & $15.0-15.7$ & $?$ & Rather slender & Sub ovoid \\
\hline M. eos & 21.5 & $26.9-27.8$ & Stout & Rounded \\
\hline M. fanjingshanensis & $19.0-22.7$ & $22.5-23.0$ & Slender & Rounded \\
\hline M. fissipes & $18.0-27.5$ & $20.0-28.0$ & Moderately slender & Rounded \\
\hline M. fodiens & $20.1-29.1$ & $20.0-30.0$ & Stout & Rounded \\
\hline M. gadjahmadai & $18.2-21.3$ & $20.4-25.5$ & Stout & Rounded \\
\hline M. heymonsi & $16.5-22.0$ & $18.0-26.5$ & Stocky & Obtusely pointed \\
\hline M. hongiaoensis & $13.6-14.7$ & $18.3-18.6$ & Slender & Bluntly rounded \\
\hline M. irrawaddy & $12.3-17.1$ & $16.7-20.9$ & Very slender & Acuminate \\
\hline M. karunaratnei & $15.8-19.1$ & $19.6-21.0$ & Moderately stocky & Rounded \\
\hline M. kodial & $16.9-17.4$ & $18.0-20.4$ & Slender & Rounded \\
\hline M. kuramotoi & $23.8-27.8$ & $28.8-34.6$ & Moderately slender & Rounded \\
\hline M. laterite & $15.3-16.6$ & 18.4 & very small sized & Obtuse \\
\hline M. maculifera & $12.0-13.3$ & 11.8 & Moderately stout & Bluntly rounded \\
\hline M. malang & $18.7-22.2$ & $19.0-23.4$ & Stocky & Rounded \\
\hline M. mantheyi & $15.0-29.2$ & $14.8-24.1$ & Stocky & Pointed \\
\hline M. marmorata & $18.8-21.5$ & $21.1-23.2$ & Moderately stocky & Bluntly rounded \\
\hline M. mihintalei & $21.7-27.3$ & 24.4 & Slender & Sub-ovoid \\
\hline M. minuta & $14.7-15.9$ & $15.7-17.2$ & Slender & Bluntly rounded \\
\hline M. mixtura & $18.8-25.2$ & $24.8-26.2$ & Stout & Rounded \\
\hline M. mukhlesuri & $16.5-21.0$ & $17.3-18.4$ & Moderately slender & Rounded \\
\hline M. mymensinghensis & $14.2-17.6$ & $15.2-21.3$ & Stocky & Truncated \\
\hline M. nanapollexa & 13.5 & 16.6 & Slender & Rounded \\
\hline M. nepenthicola & $10.6-12.8$ & $177.9-18.8$ & Slender & Obtusely pointed \\
\hline M. nilphamariensis & $14.8-20.0$ & $18.7-21.0$ & Stout & Rounded \\
\hline M. okinavensis & $20.8-25.6$ & $26.5-30.8$ & Moderately slender & Rounded \\
\hline M. orientalis & $15.8-17.4$ & $15.8-17.4$ & Moderately slender & Rounded \\
\hline M. ornata & $13.4-24.9$ & $24.9-26.2$ & Moderately slender & Rounded \\
\hline M. palmipes & 16 & 21.8 & Slender & Rounded \\
\hline M. perparva & $10.5-11.9$ & $12.4-14.5$ & Moderate & Obtusely pointed \\
\hline M. petrigena & $13.9-16.2$ & $15.1-17.8$ & Moderately stout & Obtusely pointed \\
\hline M. picta & $25.2-30.1$ & $27.2-33.4$ & Stout & Rounded \\
\hline M. pineticola s. str. & $17.4-18.6$ & $20.0-22.3$ & Stocky & Rounded \\
\hline M. pulchella & $14.7-21.6$ & $18.1-25.8$ & Moderately stocky & Bluntly rounded \\
\hline M. pulchra & $23.0-32.0$ & $28.0-36.5$ & Stocky & Obtusely pointed \\
\hline M. rubra & $20.0-27.5$ & $20.5-29.5$ & Stout & Rounded \\
\hline M. sholigari & $15.9-16.2$ & $15.9-19.2$ & Moderately slender & Truncated \\
\hline M. superciliaris & 12.7 & 12 & Slender & Rounded \\
\hline M. taraiensis & $19.9-20.9$ & $22.1-24.9$ & Stout & Rounded \\
\hline M. tetrix & $10.1-13.7$ & $15.2-17.6$ & Slender & Rounded \\
\hline M. zeylanica & $14.4-18.3$ & $15.8-20.0$ & Moderately slender & Rounded \\
\hline
\end{tabular}


Table 4 continued. Morphological comparison between Microhyla neglecta sp. nov with 52 currently recognized species of genus Microhyla. Members of the M. achatina species group are highlighted; ? = no data.

\begin{tabular}{|c|c|c|c|}
\hline Species & Skin on dorsum & F1 vs F2 & Disks on distal end of fingers \\
\hline M. neglecta sp. nov. & Smooth with few tubercles & $\mathrm{F} 1>1 / 2 \mathrm{~F} 2$ & present \\
\hline M. achatina & Smooth or feebly tubercular & $\mathrm{F} 1<1 / 2 \mathrm{~F} 2$ & present \\
\hline M. annamensis & Warty, strongly tubercular & $\mathrm{F} 1<1 / 2 \mathrm{~F} 2$ & present \\
\hline M. annectens & Smooth & $\mathrm{F} 1<1 / 2 \mathrm{~F} 2$ & present \\
\hline M. arboricola & Feebly granular & $\mathrm{F} 1<1 / 2 \mathrm{~F} 2$ & present \\
\hline M. aurantiventris & Shagreened, tiny tubercles & $\mathrm{F} 1>1 / 2 \mathrm{~F} 2$ & present \\
\hline M. beilunensis & Smooth, small tubercles & $\mathrm{F} 1<1 / 2 \mathrm{~F} 2$ & present (weak) \\
\hline M. berdmorei & Smooth, small tubercles & $\mathrm{F} 1<1 / 2 \mathrm{~F} 2$ & present (weak) \\
\hline M. borneensis & Smooth, small tubercles & nub / bulge & weak / absent \\
\hline M. butleri & Smooth or tubercular & $\mathrm{F} 1>1 / 2 \mathrm{~F} 2$ & present (weak) \\
\hline M. chakrapanii & Smooth & $\mathrm{F} 1>1 / 2 \mathrm{~F} 2$ & absent \\
\hline M. darevskii & Slightly tubercular or pustulate & $\mathrm{F} 1>1 / 2 \mathrm{~F} 2$ & absent \\
\hline M. darreli & Shagreened to sparsely granular & $\mathrm{F} 1>1 / 2 \mathrm{~F} 2$ & present (weak) \\
\hline M. eos & Smooth to shagreened & $?$ & present \\
\hline M. fanjingshanensis & Roughish with tiny tubercles & $\mathrm{F} 1>1 / 2 \mathrm{~F} 2$ & absent \\
\hline M. fissipes & Smooth or slightly tubercular & $\mathrm{F} 1>1 / 2 \mathrm{~F} 2$ & absent \\
\hline M. fodiens & Feebly tubercular & $\mathrm{F} 1<1 / 2 \mathrm{~F} 2$ & absent \\
\hline M. gadjahmadai & Low tubercles & $\mathrm{F} 1>1 / 2 \mathrm{~F} 2$ & present (weak) \\
\hline M. heymonsi & Smooth & $\mathrm{F} 1 \leq 1 / 2 \mathrm{~F} 2$ & present \\
\hline M. hongiaoensis & Low tubercles & $\mathrm{F} 1<1 / 2 \mathrm{~F} 2$ & present \\
\hline M. irrawaddy & Granular & $\mathrm{F} 1>1 / 2 \mathrm{~F} 2$ & present \\
\hline M. karunaratnei & Smooth & $\mathrm{F} 1>1 / 2 \mathrm{~F} 2$ & present \\
\hline M. kodial & Tuberculated & $\mathrm{F} 1>1 / 2 \mathrm{~F} 2$ & present \\
\hline M. kuramotoi & Smooth or slightly tubercular & $\mathrm{F} 1 \leq 1 / 2 \mathrm{~F} 2$ & absent \\
\hline M. laterite & Smooth & $\mathrm{F} 1>1 / 2 \mathrm{~F} 2$ & present \\
\hline M. maculifera & Tuberculated & $\mathrm{F} 1>1 / 2 \mathrm{~F} 2$ & absent \\
\hline M. malang & Smooth & $\mathrm{F} 1<1 / 2 \mathrm{~F} 2$ & present \\
\hline M. mantheyi & Granular, feebly pustular & $\mathrm{F} 1<1 / 2 \mathrm{~F} 2$ & present \\
\hline M. marmorata & Smooth or feebly pustular & $\mathrm{F} 1<1 / 2 \mathrm{~F} 2$ & present \\
\hline M. mihintalei & Smooth & $\mathrm{F} 1 \leq 1 / 2 \mathrm{~F} 2$ & absent \\
\hline M. minuta & Granular, feebly pustular & $\mathrm{F} 1 \leq 1 / 2 \mathrm{~F} 2$ & present \\
\hline M. mixtura & Smooth, with tubercles & $\mathrm{F} 1<1 / 2 \mathrm{~F} 2$ & present (weak) \\
\hline M. mukhlesuri & Smooth & $\mathrm{F} 1>1 / 2 \mathrm{~F} 2$ & absent \\
\hline M. mymensinghensis & Smooth & $\mathrm{F} 1>1 / 2 \mathrm{~F} 2$ & absent \\
\hline M. nanapollexa & Smooth & nub / bulge & present \\
\hline M. nepenthicola & Smooth, small tubercles & nub / bulge & weak / absent \\
\hline M. nilphamariensis & Smooth & $\mathrm{F} 1>1 / 2 \mathrm{~F} 2$ & absent \\
\hline M. okinavensis & Smooth or slightly tubercular & $\mathrm{F} 1 \leq 1 / 2 \mathrm{~F} 2$ & absent \\
\hline M. orientalis & Smooth or slightly tubercular & $\mathrm{F} 1<1 / 2 \mathrm{~F} 2$ & weak \\
\hline M. ornata & Smooth or slightly tubercular & $\mathrm{F} 1 \leq 1 / 2 \mathrm{~F} 2$ & absent \\
\hline M. palmipes & Smooth or slightly tubercular & nub / bulge & present \\
\hline M. perparva & Smooth & nub / bulge & present \\
\hline M. petrigena & Smooth, tubercles posteriorly & nub / bulge & present \\
\hline M. picta & Smooth or slightly warty & $\mathrm{F} 1<1 / 2 \mathrm{~F} 2$ & absent \\
\hline M. pineticola s. str. & Feebly granular & $\mathrm{F} 1 \leq 1 / 2 \mathrm{~F} 2$ & present \\
\hline M. pulchella & Smooth & $\mathrm{F} 1<1 / 2 \mathrm{~F} 2$ & present \\
\hline M. pulchra & Smooth, feebly granular & $\mathrm{F} 1<1 / 2 \mathrm{~F} 2$ & absent \\
\hline M. rubra & Smooth, feebly tuberculated & $\mathrm{F} 1 \leq 1 / 2 \mathrm{~F} 2$ & absent \\
\hline M. sholigari & Smooth & $\mathrm{F} 1>1 / 2 \mathrm{~F} 2$ & present \\
\hline M. superciliaris & Smooth & $\mathrm{F} 1<1 / 2 \mathrm{~F} 2$ & present \\
\hline M. taraiensis & granular & $\mathrm{F} 1>1 / 2 \mathrm{~F} 2$ & absent \\
\hline M. tetrix & Smooth & $\mathrm{F} 1=1 / 2 \mathrm{~F} 2$ & present \\
\hline M. zeylanica & Smooth or slightly tubercular & $\mathrm{F} 1>1 / 2 \mathrm{~F} 2$ & absent \\
\hline
\end{tabular}


Table 4 continued. Morphological comparison between Microhyla neglecta sp. nov with 52 currently recognized species of genus Microhyla. Members of the M. achatina species group are highlighted; ? = no data.

\begin{tabular}{|c|c|c|c|c|c|}
\hline Species & $\begin{array}{l}\text { Median longitudinal } \\
\text { grooves on dorsal } \\
\text { finger disks }\end{array}$ & $\begin{array}{l}\text { Disks at the } \\
\text { distal end of } \\
\text { toes }\end{array}$ & $\begin{array}{l}\text { Dorsal peripheral } \\
\text { grooves on } \\
\text { toe disks } \\
\end{array}$ & $\begin{array}{l}\text { metatarsal } \\
\text { tubercles }\end{array}$ & $\begin{array}{l}\text { Superciliary } \\
\text { tubercles }\end{array}$ \\
\hline M. neglecta sp. nov. & present & present & present (weak) & 2 & absent \\
\hline M. achatina & present & present & present & 2 & absent \\
\hline M. annamensis & present & present & present & 2 & absent \\
\hline M. annectens & present & present & present & 1 & absent \\
\hline M. arboricola & present (weak) & present & present & 1 & absent \\
\hline M. aurantiventris & present (weak) & present & present & 2 & absent \\
\hline M. beilunensis & absent & present & present & 2 & absent \\
\hline M. berdmorei & present & present & present & 2 & absent \\
\hline M. borneensis & present & present & present & 2 & absent \\
\hline M. butleri & present & present & present & 2 & absent \\
\hline M. chakrapanii & absent & present & absent & 2 & absent \\
\hline M. darevskii & absent & weak & present & 2 & absent \\
\hline M. darreli & absent & present (weak) & present & 2 & absent \\
\hline M. eos & absent & present & present & 2 & absent \\
\hline M. fanjingshanensis & absent & present & present & 2 & absent \\
\hline M. fissipes & absent & absent & absent & 2 & absent \\
\hline M. fodiens & absent & absent & absent & 2 & absent \\
\hline M. gadjahmadai & present & present & present & 2 & absent \\
\hline M. heymonsi & present & present & present & 2 & absent \\
\hline M. hongiaoensis & absent & present & present (weak) & 2 & absent \\
\hline M. irrawaddy & absent & absent & present (weak) & $?$ & absent \\
\hline M. karunaratnei & present & present & present & 2 & absent \\
\hline M. kodial & absent & present & absent & 2 & absent \\
\hline M. kuramotoi & absent & absent & absent & 2 & absent \\
\hline M. laterite & present & present & present & 2 & present \\
\hline M. maculifera & absent & present (weak) & absent & 1 & absent \\
\hline M. malang & present & present & present & 2 & absent \\
\hline M. mantheyi & present & present & present & 2 & absent \\
\hline M. marmorata & present & present & present & 2 & absent \\
\hline M. mihintalei & absent & absent & absent & 2 & present \\
\hline M. minuta & present (weak) & present & present & 2 & absent \\
\hline M. mixtura & absent & present & present & 2 & absent \\
\hline M. mukhlesuri & absent & absent & absent & 2 & absent \\
\hline M. mymensinghensis & absent & absent & absent & 2 & absent \\
\hline M. nanapollexa & present & present & present & 1 & absent \\
\hline M. nepenthicola & present & present & present & 2 & absent \\
\hline M. nilphamariensis & absent & absent & absent & 2 & absent \\
\hline M. okinavensis & absent & absent & absent & 2 & absent \\
\hline M. orientalis & present & present & present & 2 & absent \\
\hline M. ornata & absent & absent & absent & 2 & absent \\
\hline M. palmipes & absent & present & absent & 2 & absent \\
\hline M. perparva & absent & present & present & 1 & present \\
\hline M. petrigena & present (weak) & present & present & 1 & absent \\
\hline M. picta & absent & absent & absent & 2 & absent \\
\hline M. pineticola s. str. & present & present & present (weak) & 2 & absent \\
\hline M. pulchella & present (weak) & present & present (weak) & $1(2)$ & absent \\
\hline M. pulchra & absent & absent & absent & 2 & absent \\
\hline M. rubra & absent & absent & absent & 2 & absent \\
\hline M. sholigari & absent & present & present & 2 & absent \\
\hline M. superciliaris & absent & present & present (weak) & 2 & present \\
\hline M. taraiensis & absent & absent & absent & 2 & absent \\
\hline M. tetrix & absent & present & present (weak) & 2 & absent \\
\hline M. zeylanica & absent & present & absent & 2 & absent \\
\hline
\end{tabular}


Table 4 continued. Morphological comparison between Microhyla neglecta sp. nov with 52 currently recognized species of genus Microhyla. Members of the M. achatina species group are highlighted; ? = no data.

\begin{tabular}{|c|c|c|c|}
\hline Species & $\begin{array}{l}\text { Light dorsomedial } \\
\text { (vertebral) line }\end{array}$ & $\begin{array}{l}\text { Tibiotarsal articulation } \\
\text { reaches }\end{array}$ & Toe webbing formula \\
\hline M. neglecta sp. nov. & present & Well beyond snout & I1 1/2-21/2II13/4-3III23/4-33/4IV33/4-21/2V \\
\hline M. achatina & present & To snout or just beyond & I2-21/2II2-31/4III3-4IV 4- 3V \\
\hline M. annamensis & absent & Well beyond snout & I1-21/4II1-21/2III11/2-23/4IV3-1V \\
\hline M. annectens & absent & Well beyond eye & I1-1II1-1III1-3IV3-1V \\
\hline M. arboricola & absent & Well beyond snout & $\mathrm{I} 1^{2} / 3-21 / 4 \mathrm{II} 2-3 \mathrm{III} 21 / 2-31 / 2 \mathrm{IV} 3-1 \frac{1}{2} \mathrm{~V}$ \\
\hline M. aurantiventris & absent & Slightly beyond snout & $\mathrm{I} 13 / 4-2 \mathrm{II} 11 / 2-23 / 4 \mathrm{III} 2-3^{1 / 3} \mathrm{IV} 31 / 4-11 / 2 \mathrm{~V}$ \\
\hline M. beilunensis & absent & To the eye & Basal \\
\hline M. berdmorei & absent & Well beyond snout & I1-1II1-2III1-2IV2-1V \\
\hline M. borneensis & absent & Shorter than snout & I1-2II1-3III $2^{1 / 2} 2-31 / 3$ IV3 $1 / 2-2 V$ \\
\hline M. butleri & absent & Shorter than snout & $\mathrm{I} 2-2^{1 / 2 \mathrm{II}} 1^{3} / 4-3 \mathrm{III} 2^{1 / 3}-31 \frac{1}{2} \mathrm{IV} 31 / 2-2^{1 / 4} \mathrm{~V}$ \\
\hline M. chakrapanii & absent & Beyond snout (?) & Basal \\
\hline M. darevskii & absent & Well beyond snout & I1-1II1-1III1-1IV1-1V \\
\hline M. darreli & absent & Shorter than eye & I2-21/4II13/4 -3IIII-3IV3-21/4V \\
\hline M. eos & absent & $?$ & $\mathrm{I} 1 \frac{1}{2}-2^{+} \mathrm{II} 1^{2} / 3-3 \mathrm{III} 2^{1 / 2}-\mathrm{IV} 4^{-}-1 \frac{1}{2} \mathrm{~V}$ \\
\hline M. fanjingshanensis & present & Between eye to nostril & Basal \\
\hline M. fissipes & absent & Shorter than snout & I2-21/2II2-31/2III3-4IV4-3V \\
\hline M. fodiens & absent & Shorter than eye & I1-2II13/4-3III23/4-33/4IV 4-23/4V \\
\hline M. gadjahmadai & present & Well beyond snout & I2-21/4II13/4-3IIII3-4IV4-23/4V \\
\hline M. heymonsi & present & Shorter than snout & I2-21/2II2-3III3-4IV41/3-3V \\
\hline M. hongiaoensis & absent & Well beyond snout & I1-2II $1-2 \frac{1}{2} 2 \mathrm{III} 1-21 / 2 \mathrm{IV} 2 \frac{1}{2} 2-1 \mathrm{~V}$ \\
\hline M. irrawaddy & absent & To the eye & I2-3II2-3III3-41/2IV41/2-23/4V \\
\hline M. karunaratnei & absent & Beyond snout (?) & I2-21/2 II $2-31 / 2$ III $21 / 2-33 / 4$ IV4-2V \\
\hline M. kodial & absent & Well beyond snout & Basal \\
\hline M. kuramotoi & absent & To the eye & I2-2II2-3III3-4IV4-24/5 V \\
\hline M. laterite & absent & Well beyond snout & I1-2II1-2III12/3-2IV3-1V \\
\hline M. maculifera & absent & To snout or just beyond & Basal \\
\hline M. malang & absent & To snout or just beyond & I1-2II1-2 $2 / 3$ IIII $12 / 3-3 I V 3-1 \mathrm{~V}$ \\
\hline M. mantheyi & absent & Well beyond snout & I1-2II1-2III2-3IV3-11/2V \\
\hline M. marmorata & absent & Well beyond snout & I1-2II1-13/4III11/2-23/4IV23/4-1V \\
\hline M. mihintalei & absent & To snout & Basal \\
\hline M. minuta & absent & Shorter than snout & In.a.-n.a.II2-31/2III3-4IV4-3V \\
\hline M. mixtura & absent & Shorter than snout & I2-21/2III3/4-31/4IIII3-4IV41/4-23/4V \\
\hline M. mukhlesuri & absent & To snout & $\mathrm{I} 2-21 / 2 \mathrm{II} 2-31 / 2 \mathrm{III} 3-4 \mathrm{IV} 4-23 / 4 \mathrm{~V}$ \\
\hline M. mymensinghensis & absent & To snout & $\mathrm{I} 2-2^{1 / 2 \mathrm{II}} 2-31 / 2 \mathrm{III} 3-4 \mathrm{IV} 41 / 4-23 / 4 \mathrm{~V}$ \\
\hline M. nanapollexa & absent & Well beyond snout & I1-2II $1-2^{1 / 2 I I I} 2^{1 / 2}-21 / 2 I V 21 / 2-1 V$ \\
\hline M. nepenthicola & absent & Shorter than snout & $?$ \\
\hline M. nilphamariensis & absent & To snout & Basal \\
\hline M. okinavensis & absent & Beyond eye & 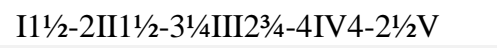 \\
\hline M. orientalis & present & To the eye & In.a.-n.a.II2-31/4III3-41/4IV41/4-3V \\
\hline M. ornata & absent & Shorter than snout & I2-21/2II13/4-31/2III3-4IV4-23/4V \\
\hline M. palmipes & absent & To snout or just beyond & In.a.-n.a.II $21 / 3-33 / 4$ IIII $31 / 4-4 I V 4-3 V$ \\
\hline M. perparva & absent & Well beyond snout & I1-1II1-1III1-2IV2-1V \\
\hline M. petrigena & absent & Well beyond snout & I1-1II1-1III1-2IV2-1V \\
\hline M. picta & absent & Shorter than eye & $\mathrm{I} 2-2^{3} / 4 \mathrm{II} 13 / 4-23 / 4 \mathrm{III} 2^{3 / 4}-33 / 4 \mathrm{IV} 4-21 / 2 \mathrm{~V}$ \\
\hline M. pineticola s. str. & present & Shorter than snout & I1 1/2-21/2II13/4-3IIII $3 / 4-33 / 4 \mathrm{IV} 4-21 / 2 \mathrm{~V}$ \\
\hline M. pulchella & absent & Well beyond snout & I1 1/2-2II1-2III1-21/2IV21/4-1V \\
\hline M. pulchra & absent & To snout or just beyond & I11/2-2II1-3III2-31/4IV31/2-2V \\
\hline M. rubra & absent & Shorter than snout & 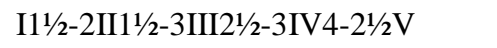 \\
\hline M. sholigari & present & Shorter than snout & I1 $1 / 2-2 \mathrm{II} 21 / 2-31 / 2 \mathrm{III} 21 / 2-31 / 2 \mathrm{IV} 33 / 4-2 \mathrm{~V}$ \\
\hline M. superciliaris & absent & To snout or just beyond & I1-1II1-1III1-2IV2-1V \\
\hline M. taraiensis & absent & To the snout & I2-3II23/4-33/4III3-41/4IV4-23/4V \\
\hline M. tetrix & absent & Well beyond snout & I1-2II1-2III1-21/2IV21/2-1V \\
\hline M. zeylanica & absent & To the eye & $\mathrm{I} 2-2^{1 / 4 I I} 1^{3 / 4}-31 / 2 \mathrm{III} 2^{1 / 4}-33 / 4 \mathrm{IV} 4-2 \mathrm{~V}$ \\
\hline
\end{tabular}


Table 4 continued. Morphological comparison between Microhyla neglecta sp. nov with 52 currently recognized species of genus Microhyla. Members of the M. achatina species group are highlighted; ? = no data.

\begin{tabular}{|c|c|c|}
\hline Species & Distribution & Sources \\
\hline M. neglecta sp. nov. & Vietnam (Langbian pl.) & our data \\
\hline M. achatina & Indonesia (Java) & Poyarkov et al. 2014; Atmaja et al. 2018 \\
\hline M. annamensis & Vietnam (Langbian pl.) & Poyarkov et al. 2014; our data \\
\hline M. annectens & Thailand, Malaysia & Parker 1928; Poyarkov et al. 2014; our data \\
\hline M. arboricola & Vietnam (Langbian pl.) & Poyarkov et al. 2014 \\
\hline M. aurantiventris & Vietnam (Kon Tum pl.) & Nguyen et al. 2019 \\
\hline M. beilunensis & China & Zhang et al. 2018 \\
\hline M. berdmorei & Indo-Burma and Sundaland & Poyarkov et al. 2014; Garg et al. 2018; our data \\
\hline M. borneensis & Malaysia (Borneo) & Das \& Haas 2010; Matsui 2011 \\
\hline M. butleri & Indo-Burma and Sundaland & Poyarkov et al. 2014, 2020a; our data \\
\hline M. chakrapanii & India (Andamans) & Pilayi 1977 \\
\hline M. darevskii & Vietnam (Kon Tum pl.) & Poyarkov et al. 2014; our data \\
\hline M. darreli & India & Garg et al. 2018 \\
\hline M. eos & India & Biju et al. 2019 \\
\hline M. fanjingshanensis & China & Li et al. 2019 \\
\hline M. fissipes & China, Vietnam & Poyarkov et al. 2014; Garg et al. 2018; our data \\
\hline M. fodiens & Myanmar & Poyarkov et al. 2019 \\
\hline M. gadjahmadai & Indonesia (Sumatra) & Atmaja et al. 2018 \\
\hline M. heymonsi & Indo-Burma and Sundaland & Poyarkov et al. 2014; Garg et al. 2018; our data \\
\hline M. hongiaoensis & Vietnam (Langbian pl.) & Hoang et al. 2020 \\
\hline M. irrawaddy & Myanmar & Poyarkov et al. 2019 \\
\hline M. karunaratnei & Sri Lanka & Garg et al. 2018 \\
\hline M. kodial & India & Vineeth et al. 2018 \\
\hline M. kuramotoi & Japan (Yaeyama) & Matsui \& Tomiaga 2020 \\
\hline M. laterite & India & Seshadri et al. 2016 \\
\hline M. maculifera & Malaysia (Borneo) & Poyarkov et al. 2014; our data \\
\hline M. malang & Malaysia (Borneo) & Matsui 2011 \\
\hline M. mantheyi & Thailand, Malaysia, Singapore & Das et al. 2007; our data \\
\hline M. marmorata & Vietnam, Laos & Bain \& Nguyen 2004; our data \\
\hline M. mihintalei & Sri Lanka & Wijayathilaka et al. 2016; Garg et al. 2018 \\
\hline M. minuta & Vietnam (Langbian pl.) & Poyarkov et al. 2014; our data \\
\hline M. mixtura & China & Poyarkov et al. 2014; Zhang et al. 2018 \\
\hline M. mukhlesuri & Bangladesh, Myanmar, Indochina, Thailand & Hasan et al. 2014; Garg et al. 2018; our study \\
\hline M. mymensinghensis & Bangladesh, India & Hasan et al. 2014; Garg et al. 2018 \\
\hline M. nanapollexa & Vietnam (Kon Tum pl.) & Bain \& Nguyen, 2004; our data \\
\hline M. nepenthicola & Malaysia (Borneo) & Das \& Haas 2010; Matsui 2011 \\
\hline M. nilphamariensis & Bangladesh, Nepal, India, Pakistan & Howlader et al. 2015; Garg et al. 2018 \\
\hline M. okinavensis & Japan (Miyako, Okinawa, Amami) & Matsui \& Tomiaga 2020 \\
\hline M. orientalis & Indonesia & Matsui et al. 2013 \\
\hline M. ornata & Sri Lanka, India & Poyarkov et al. 2014; Garg et al. 2018 \\
\hline M. palmipes & Indonesia (Sumatra, Nias, Java, Bali) & Poyarkov et al. 2014 \\
\hline M. perparva & Malaysia (Borneo) & Poyarkov et al. 2014; Inger et al. 2017 \\
\hline M. petrigena & Malaysia (Borneo) & Poyarkov et al. 2014; Inger et al. 2017 \\
\hline M. picta & Vietnam (Low central-souther) & Poyarkov et al. 2014; our data \\
\hline M. pineticola s. str. & Vietnam (Langbian pl.) & Poyarkov et al. 2014; our data \\
\hline M. pulchella & Vietnam (Langbian pl.) & Poyarkov et al. 2014 \\
\hline M. pulchra & China, Indochina, Thailand & Poyarkov et al. 2014; our data \\
\hline M. rubra & India & Poyarkov et al. 2014; Garg et al 2018 \\
\hline M. sholigari & India & Dutta \& Ray 2000; Garg et al. 2018 \\
\hline M. superciliaris & Thailand, Malaysia, Indonesia & Poyarkov et al. 2014, 2020b \\
\hline M. taraiensis & Nepal & Khatiwada et al. 2017; Garg et al. 2018 \\
\hline M. tetrix & Thailand & Poyarkov et al. $2020 \mathrm{~b}$ \\
\hline M. zeylanica & Sri Lanka & Poyarkov et al. 2014; Garg et al. 2018 \\
\hline
\end{tabular}




\section{Discussion}

In this paper we report on a new species of the genus Microhyla discovered from the montane forests of Langbian Plateau, southern Vietnam. This discovery underscores the high degree of site-specific endemism in isolated montane regions within the Truong Son, or Annamite mountains (e.g. Orlov et al. 2012, Hartmann et al. 2013, Geissler et al. 2015a-b, Chen et al. 2018, Nguyen et al. 2018, 2019, Poyarkov et al. 2017, 2019b). The Langbian Plateau is widely recognized as the centre of herpetofaunal endemism and diversity in Indochina (e.g. Poyarkov \& Vassilieva 2011, Nazarov et al. 2012, Vassilieva et al. 2014, Poyarkov et al. 2014, 2015a, 2015b, 2017, 2018, 2019b, Duong et al. 2018, Pauwels et al. 2018). Our discovery of $M$. neglecta brings the total number of species in the genus in Vietnam to 17, with the greatest species diversity and highest degree of local endemism occurring in the Central Highlandsalso known as Tay Nguyen Region-that encompass the Kon Tum and Langbian plateaus. Based on the recent progress in Microhyla taxonomy in Vietnam (Poyarkov et al. 2014, Hoang et al. 2020, and this study), up to 12 sympatric species of Microhyla are known to cooccur in the montane forests of the Langbian Plateau and its surrounding areas, many of which can be recorded in the same biotope. This is the highest known species density for the genus Microhyla in the world, which further highlights the importance of the Langbian Plateau for the evolution and ecological differentiation in this group of frogs (for discussion see Gorin et al. 2020).

The present description of $M$. neglecta is especially interesting as it was confused with its morphologically similar cryptic sister species $M$. pineticola for more than 10 years. In their review, Poyarkov et al. (2014) relied exclusively on morphological characters which they used to distinguish "M. pineticola" sensu lato from the morphologically similar widespread species $M$. heymonsi. They reported a significant variation in colouration, pattern, and morphometrics within the type series of $M$. pineticola, but due to the lack of genetic data and sympatric cooccurrence of the two species, they misinterpreted it as a high degree of intraspecific variability (Poyarkov et al. 2014: 100-111). The integrative taxonomic analysis of the material reported by Poyarkov et al. (2014) and the newly collected samples have demonstrated that the diversity hidden within the name " $M$. pineticola" was overlooked. Such situations are rare, but occasionally happen in taxonomic practice. For example, when first discovered, the specimens of a small-sized gecko species Cnemaspis pseudomcguirei Grismer, Ahmad, Chan et al., 2009 were confused with juveniles of a larger sympatric species C. mcguirei Grismer, Wood \& Chan, 2008 (Grismer et al. 2008, 2009). This underscores the key importance of integrative approaches, including molecular data for any taxonomic revision. Not only is this paramount for any downstream analyses, it is now also recognized as a cornerstone of biodiversity conservation (Shaffer et al. 2015). We further stress that in the age of biodiversity crises and molecular genetics, the systematic collection of tissue samples and application of molecular methods is crucial for taxonomic practice in studies of herpetofaunal diversity in Southeast Asia (Smith et al. 2008, Murphy et al. 2013, Chomdej et al. 2020).

In our study we report on two morphologically highly similar (cryptic) species of Microhyla frogs, which co-occur sympatrically within their narrow distribution area restricted to the Langbian Plateau of southern Vietnam. Moreover, our phylogenetic analyses have demonstrated that these two cryptic taxa $M$. pineticola and $M$. neglecta are sister species and their age of divergence likely corresponds to middle Miocene (see Gorin et al. 2020). The miniaturized body size of these species (SVL below $23 \mathrm{~mm}$ ), along with the microendemic pattern of their distribution, suggest that the non-allopatric scenarios for their speciation have to be considered in future (see Wollenberg et al. 2011). Though allopatric speciation has been considered the main process leading to species diversity (Mayr 1982), a number of studies demonstrated that species formation may occur in parapatric or sympatric settings as well (Via 2001, 2009, Seehausen et al. 2008). In amphibians, sympatric scenarios of speciation have only been rarely discussed (see Steinfartz et al. 2007, Vences \& Wake 2007, Wollenberg et al. 2011, Vences et al. 2012). The statistical analysis by Wollenberg et al. (2011) suggested that microendemic species of miniaturized frogs tend to speciate more readily and may reject the predominance of allopatric speciation. Interestingly enough, the Langbian Plateau provides further examples of sympatric co-occurrence of sister species in amphibians, such as Microhyla pulchella and $M$. 
hongiaoensis (Poyarkov et al. 2014, Hoang et al. 2020), and Ophryophryne gerti (Ohler, 2003) and $O$. elfina Poyarkov, Duong, Orlov et al. 2017 (Megophryidae; see Poyarkov et al. 2017). We recommend that future studies on adaptive speciation and diversification in amphibians should target the Langbian Plateau, as additional pairs of diverging populations and cryptic species are likely to be found, providing further evidence for the possibility of non-allopatric adaptive speciation in the amphibians in this area or a shared historical environmental history resulting in co-occurring speciation events.

Despite the recent increase in species discoveries, many areas of the Annamites have received comparatively little scientific attention and are very likely to harbour additional, previously unknown species (Poyarkov et al. 2014). The need for biological exploration in this region is made more urgent given the ongoing loss of natural habitats due to logging, road construction, increasing agricultural pressure and other human activities (Meijer 1973, De Koninck 1999, Laurance 2007, Meyfroidt \& Lambin 2008, Kuznetsov \& Kuznetsova 2011).

\section{Acknowledgements}

Fieldwork was funded by the Joint RussianVietnamese Tropical and Technological Center (JRVTTC) and was conducted under permission of the Bureau of Forestry, Ministry of Agriculture and Rural Development of Vietnam (permits Nos. 170/ TCLN-BTTN of 07/02/2013; 400/TCLN-BTTN of $26 / 03 / 2014 ; 831 /$ TCLNBTTN of 05/07/2013) and of local administration (Lam Dong Province: No. 5832/UBND-LN of 22/10/12; Dak Lak Province: \#1567/UBND-TH, issued 06 April 2011; \#388/SNgV-LS, issued 24 April 2019; \#995/SNN-CCKL, issued 12 April 2019). The authors are grateful to Andrey N. Kuznetsov (JRVTTC) and Thai Van Nguyen (SVW) for supporting our study. We thank Eduard A. Galoyan, Anna B. Vassilieva, Eugene S. Popov, Alina V. Alexandrova and Olga V. Morozova for help and support during the field work. The authors are grateful to Chris Joldnall for proofreading of the paper. We thank Chris Joldnall and Eugene S. Popov for proofreading the manuscript and linguistic help. We express our sincere gratitude to Lee Grismer (La Sierra University, USA), Indraneil Das (University of Malaysia, Sarawak), and Peter Geissler (ZFMK, Germany) for reviewing the manuscript.
Fieldwork, specimen collection, and molecular phylogenetic analysis for this paper were conducted with the financial support of the Russian Science Foundation (RSF Grant No. 1914-00050 to Nikolay A. Poyarkov, molecular analysis); specimen examination and morphological analysis was funded by the Russian Foundation of Basic Research to Nikolay A. Poyarkov (RFBR grant No. 19-3490167). This work was supported by the Moscow State University Grant for Leading Scientific Schools 'Depository of the Living Systems' in the framework of the MSU Development Program to Nikolay A. Poyarkov.

\section{Literature cited}

Atmaja, V.Y., A. Hamidy, T. Arisuryanti, M. Matsui, E.N. Smith (2019). A new species of Microhyla (Anura: Microhylidae) from Sumatra, Indonesia. Treubia, 45: 25-46.

Bain, R.H. and T.Q. Nguyen (2004). Three new species of narrow-mouth frogs (Genus: Microhyla) from Indochina, with comments on Microhyla annamensis and Microhyla palmipes. Copeia, 2004 (3): 507-524.

Biju, S.D., S. Garg, R.G. Kamei, and G. Maheswaran (2019). A new Microhyla species (Anura: Microhylidae) from riparian evergreen forest in the eastern Himalayan state of Arunachal Pradesh, India. Zootaxa, 4674 (1): 100-116.

Bui M.Q, M.A.T. Nguyen, and von A. Haeseler (2013). Ultrafast approximation for phylogenetic bootstrap. Molecular Biology \& Evolution, 30: 1188-1195.

Chen, J.M., N.A. Poyarkov, C. Suwannapoom, A. Lathrop, Y.-H. Wu et al. (2018). Large-scale phylogenetic analyses provide insights into unrecognized diversity and historical biogeography of Asian leaf-litter frogs, genus Leptolalax (Anura: Megophryidae). Molecular Phylogenetics \& Evolution, 124: 162-171.

Das, I. and A. Haas (2010). New species of Microhyla from Sarawak: Old World's smallest frogs crawl out of miniature pitcher plants on Borneo (Amphibia: Anura: Microhylidae). Zootaxa, 2571: 37-52.

Das, I., P.Y. Min, W.W. Hsu, S.T. Hertwig, and A. Haas (2014). Red hot chili pepper. A new Calluella Stoliczka, 1872 (Lissamphibia: Anura: Microhylidae) from Sarawak, East Malaysia (Borneo). Zootaxa, 3785 (4): 550560.

Das, I., N.S. Yaakob, and J. Sukumaran (2007). A new species of Microhyla (Anura: Microhylidae) from the Malay Peninsula. Hamadryad, 31 (2): 304-314. 
De Koninck, R. (1999). Deforestation in Viet Nam. International Research Centre, Ottawa: 101pp.

Deng, X., S. Wang, X. Liang, J. Jiang, B. Wang, and L. Deng (2016). The complete mitochondrial genome of Kaloula rugifera (Amphibia, Anura, Microhylidae). Mitochondrial DNA Part A, 27 (5): 33913392.

Duong, T.V., D.T. Do, C.D. Ngo, T.Q. Nguyen, and N.A. Poyarkov (2018). A new species of the genus Leptolalax (Anura: Megophryidae) from southern Vietnam. Zoological Research, 38 (3): 181-196.

Dutta, S.K. and P. Ray (2000). Microhyla sholigari, a new species of microhylid frog (Anura: Microhylidae) from Karnataka, India. Hamadryad, 25: 38-44.

Frost, D.R. (2020). Amphibian Species of the World: an Online Reference. Version 6.0. Electronic Database accessible. American Museum of Natural History, New York <http://research.amnh.org/herpetology/amphib ia/index.html > Accessed on 4 October 2020.

Garg, S., R. Suyesh, A. Das, J.P. Jiang, N. Wijayathilaka et al. (2018). Systematic revision of Microhyla (Microhylidae) frogs of South Asia: a molecular, morphological, and acoustic assessment. Vertebrate Zoology, 69: $1-71$.

Geissler, P., T. Hartmann, F. Ihlow, D. Rödder, N.A.Poyarkov et al. (2015b). The Lower Mekong: an insurmountable barrier to amphibians in southern Indochina? Biological Journal of the Linnean Society, 114 (4): 905914.

Geissler, P., N.A. Poyarkov, L. Grismer, T.Q. Nguyen, H.T. An et al. (2015a). New Ichthyophis species from Indochina (Gymnophiona, Ichthyophiidae): 1. The unstriped forms with descriptions of three new species and the redescriptions of I. acuminatus Taylor, 1960, I. youngorum Taylor, 1960 and I. laosensis Taylor, 1969. Organisms Diversity \& Evolution, 15 (1): 143-174.

Gorin, V.A., E.N. Solovyeva, M. Hasan, H. Okamiya, D.M.S.S. Karunarathna et al. (2020). A little frog leaps a long way: compounded colonizations of the Indian Subcontinent discovered in the tiny Oriental frog genus Microhyla (Amphibia: Microhylidae). PeerJ, 8 e9411.

Grismer, L.L., J.L. Grismer, P.L. Wood, K.O. Chan (2008). The distribution, taxonomy, and redescription of the geckos Cnemaspis affinis (Stoliczka 1887) and C. flavolineata (Nicholls 1949) with descriptions of a new montane species and two new lowland, karst- dwelling species from Peninsular Malaysia. Zootaxa, 1931: 1-24.

Grismer, L.L., N. Ahmad, K.O. Chan, D. Belabut, M.A. Muin et al. (2009). Two new diminutive species of Cnemaspis Strauch 1887 (Squamata: Gekkonidae) from Peninsular Malaysia. Zootaxa, 2019: 40-56.

Hall, T.A. (1999). BioEdit: a user-friendly biological sequence alignment editor and analysis program for Windows 95/98/NT. In: Nucleic acids symposium series. Information Retrieval Ltd., London: 95-98.

Hartmann, T., P. Geissler, N.A. Poyarkov, F. Ihlow, E.A. Galoyan et al. (2013). A new species of the genus Calotes Cuvier, 1817 (Squamata: Agamidae) from southern Vietnam. Zootaxa, 3599 (3): 246-260.

Hasan, M., M.M. Islam, M.M.R. Khan, M.S. Alam, A. Kurabayashi et al. (2012). Cryptic anuran biodiversity in Bangladesh revealed by mitochondrial $16 \mathrm{~S}$ rRNA gene sequences. Zoological Science, 29 (3): 162-172.

Hasan, M., M.M. Islam, M. Kuramoto, A. Kurabayashi, and M. Sumida (2014). Description of two new species of Microhyla (Anura: Microhylidae) from Bangladesh. Zootaxa, 3755 (5): 401-408.

Hillis, D.M., C. Moritz, B.K. Mable, and D. Graur (1996). Molecular Systematics, $2^{\text {nd }}$ edition. Sinauer Associates, Sunderland: 655pp.

Hoang, C.V., T.T. Nguyen, A.M. Luong, T.Q. Nguyen, N.L. Orlov et al. (2020). A new species of Microhyla (Amphibia: Anura: Microhylidae) from Langbian Plateau, central Vietnam. Asian Herpetological Research, 11 (3): 161-182.

Hoang, D.T., O. Chernomor, A. von Haeseler, M.Q. Bui, and V.S. Le (2018). UFBoot2: Improving the ultrafast bootstrap approximation. Molecular Biology \& Evolution, 35: 518-522.

Howlader, M.S.A., A. Nair, S.V. Gopalan, and J. Merilä (2015). A new species of Microhyla (Anura: Microhylidae) from Nilphamari, Bangladesh. PLoS One, 10 (3): e0119825.

Huelsenbeck, J.P. and D.M. Hillis (1993). Success of phylogenetic methods in the four-taxon case. Systematic Biology, 42 (3): 247-264.

Huelsenbeck, J.P. and F. Ronquist (2001). MrBayes: bayesian inference of phylogenetic trees. Bioinformatics, 17: 754-755.

ICZN (1999). International Code of Zoological Nomenclature, $4^{\text {th }}$ edition. International Trust for Zoological Nomenclature, London: 306pp.

IUCN Standards and Petitions Subcommittee (2019). Guidelines for Using the IUCN Red List Categories and Criteria. Version 14. 
Prepared by the Standards and Petitions Subcommittee, IUCN: 113pp.

Katoh, K., K. Misawa, K. Kuma, T. Miyata (2002). MAFFT: a novel method for rapid multiple sequence alignment based on fast Fourier transform. Nucleic Acids Research, 30 (14): 3059-3066.

Khatiwada, J.R., G.C. Shu, S.H. Wang, A. Thapa, B. Wang et al. (2017). A new species of the genus Microhyla (Anura: Microhylidae) from Eastern Nepal. Zootaxa, 4254 (2): 221-239.

Khatiwada, J.R., S. Wang, G. Shu, F. Xie, and J. Jiang (2018). The mitochondrial genome of the Microhyla taraiensis (Anura: Microhylidae) and related phylogenetic analyses. Conservation Genetics Resources, 10 (3): 441-444.

Kuznetsov, A.N. and S.P. Kuznetsova (2011). Chuong 2. Thực vật VQG Bidoup-Núi Bà [Chapter 5. Reptiles and Amphibians of Bidoup-Nui Ba National Park]. In: Nguyen, D.H. and A.N. Kuznetsov (eds.). Đa dạng sinh học và đặc trung sinh thái Vuờn Quốc gia Bidoup-Núi Bà, Publishing house for Science and Technology Hanoi: 37-105pp. [In Vietnamese].

Laurance, W.F. (2007). Forest destruction in tropical Asia. Current Science, 93 (11): 15441550.

Li, S., M. Zhang, N. Xu, J. Lu, J.P. Jiang et al. (2019). A new species of the genus Microhyla (Amphibia: Anura: Microhylidae) from Guizhou Province, China. Zootaxa, 4624: 551-575.

Matsui, M. (2011). Taxonomic revision of one of the Old World's smallest frogs, with description of a new Bornean Microhyla (Amphibia, Microhylidae). Zootaxa, 2814 (1): 33-49.

Matsui, M. and A. Tominaga (2020). Distinct species status of a Microhyla from the Yaeyama Group of the southern Ryukyus, Japan (Amphibia, Anura, Microhylidae). Current Herpetology, 39: 120-136.

Matsui, M., A. Hamidy, and K. Eto (2013). Description of a new species of Microhyla from Bali, Indonesia (Amphibia, Anura). Zootaxa, 3670 (4): 579-590.

Matsui, M., A. Hamidy, D.M. Belabut, N. Ahmad, S. Panha et al. (2011). Systematic relationships of Oriental tiny frogs of the family Microhylidae (Amphibia, Anura) as revealed by mtDNA genealogy. Molecular Phylogenetics \& Evolution, 61 (1): 167-176.

Matsui, M., H. Ito, T. Shimada, H. Ota, S.K. Saidapur et al. (2005). Taxonomic relationships within the pan-Oriental narrowmouth toad Microhyla ornata as revealed by mtDNA analysis (Amphibia, Anura, Microhylidae). Zoological Science, 22(4): 489-495.

Mayr, E. (1982). Processes of speciation in animals. In: Liss, A.R.I. (ed.). Mechanisms of Speciation, Alan R. Liss Inc., New York: 1-19.

Meijer, W. (1973). Devastation and Regeneration of Lowland Dipterocarp Forests in Southeast Asia. BioScience, 23 (9): 528-533.

Meyfroidt, P. and E.F. Lambin (2008). Forest transition in Vietnam and its environmental impacts. Global Change Biology, 14 (6): 1319-1336.

Mulcahy, D.G., J.L. Lee, A.H. Miller, M. Chand, M.K. Thura, and G.R. Zug (2018). Filling the BINs of life: Report of an amphibian and reptile survey of the Tanintharyi (Tenasserim) Region of Myanmar, with DNA barcode data. ZooKeys, 757: 85-152.

Murphy, R.W., A.J. Crawford, A.M. Bauer, J. Che et al. (2013). Cold Code: the global initiative to DNA barcode amphibians and nonavian reptiles. Molecular Ecology Resources, 13 (2): 161-167.

Nazarov, R., N.A. Poyarkov, N.L. Orlov, T.M. Phung et al. (2012). Two new cryptic species of the Cyrtodactylus irregularis complex (Squamata: Gekkonidae) from southern Vietnam. Zootaxa, 3302: 1-24.

Nguyen, L.T., N.A. Poyarkov, D.T. Le, B.D. Vo et al. (2018). A new species of Leptolalax (Anura: Megophryidae) from Son Tra Peninsula, Central Vietnam. Zootaxa, 4388 (1): $1-21$.

Nguyen, L.T., N.A. Poyarkov, T.T. Nguyen, T.A. Nguyen, V.H. Tran et al. (2019). A new species of the genus Microhyla Tschudi, 1838 (Amphibia: Anura: Microhylidae) from Tay Nguyen Plateau, Central Vietnam. Zootaxa, 4543: 549-580.

Nguyen, L.T., H.A. Schmidt, A. von Haeseler, and M.Q. Bui (2015). IQ-TREE: A fast and effective stochastic algorithm for estimating maximum likelihood phylogenies. Molecular Biology \& Evolution, 32: 268-274.

Orlov, N.L., N.A. Poyarkov, A.B. Vassilieva, N.B. Ananjeva et al. (2012) Taxonomic notes on Rhacophorid frogs (Rhacophorinae: Rhacophoridae: Anura) of southern part of Annamite Mountains (Truong Son, Vietnam), with description of three new species. Russian Journal of Herpetology, 19 (1): 23-64.

Parker, H.W. (1928). LXIII. The brevicipitid frogs of the genus Microhyla. Journal of Natural History, 2 (11): 473-499. 
Parker, H.W. (1934). Monograph of the frogs of the family Microhylidae. Trustees of the British Museum, London: 212pp.

Pauwels, O.S.G., R.A. Nazarov, V.V. Bobrov, and N.A. Poyarkov (2018). Taxonomic status of two populations of Bent-toed Geckos of the Cyrtodactylus irregularis complex (Squamata: Gekkonidae) with description of a new species from Nui Chua National Park, southern Vietnam. Zootaxa, 4403 (2): 307-335.

Peloso, P.L., D.R. Frost, S.J. Richards, M.T. Rodrigues, S. Donnellan et al. (2016). The impact of anchored phylogenomics and taxon sampling on phylogenetic inference in narrowmouthed frogs (Anura, Microhylidae). Cladistics, 32 (2): 113-140.

Pillai, R. (1977). On two frogs of the family Microhylidae from Andamans including a new species. In: Proceedings of the Indian Academy of Sciences, Section-B: 135-138pp.

Poyarkov [Paiarkov], N.A. and A.B. Vasilieva (2011). Chương 5. Bò sát — Lưỡng cư VQG (Vườn Quốc gia) Bidoup-Núi Bà [Chapter 5 . Reptiles and Amphibians of Bidoup-Nui Ba National Park]. In: Nguyen, D.H. and A.N. Kuznetsov (eds.). Đa dạng sinh hoc và đặc trung sinh thái Vưòn Quốc gia Bidoup-Núi Bà Publishing house for Science and Technology Hanoi: 169-220pp [In Vietnamese].

Poyarkov, N.A., T.V. Duong, N.L. Orlov, S.S. Gogoleva et al. (2017). Molecular, morphological and acoustic assessment of the genus Ophryophryne (Anura, Megophryidae) from Langbian Plateau, southern Vietnam, with description of a new species. ZooKeys, 672: 49-120.

Poyarkov, N.A., V.A. Gorin, Tha Zaw, V.D. Kretova, S.I. Gogoleva et al. (2019a). On the road to Mandalay: contribution to the Microhyla Tschudi, 1838 (Amphibia: Anura: Microhylidae) fauna of Myanmar with description of two new species. Zoological Research, 40 (4): 244-276.

Poyarkov, N.A., I.I. Kropachev, S.S. Gogoleva, and N.L. Orlov (2018). A new species of the genus Theloderma Tschudi, 1838 (Amphibia, Anura, Rhacophoridae) from Tay Nguyen Plateau, central Vietnam. Zoological Research, 38 (3): 156-180.

Poyarkov, N.A., T.V. Nguyen, N.L. Orlov, and G. Vogel (2019b). A new species of the genus Calamaria Boie, 1827 from the highlands of the Langbian Plateau, Southern Vietnam (Squamata: Colubridae). Russian Journal of Herpetology, 26 (6): 335-348.

Poyarkov, N.A., N.L. Orlov, A.V. Moiseeva, P. Pawangkhanant et al. (2015b). Sorting out moss frogs: mtDNA data on taxonomic diversity and phylogenetic relationships of the Indochinese species of the genus Theloderma (Anura, Rhacophoridae). Russian Journal of Herpetology, 22 (4): 241-280.

Poyarkov, N.A., P. Pawangkhanant, V.A. Gorin, W. Juthong, C. Suwannapoom (2020b). A new species of miniaturised narrow-mouth frog of the genus Microhyla Tschudi, 1838 (Amphibia: Anura: Microhylidae) from northern Tenasserim, Thailand. Journal of Natural History, 54 (23-24): 1525-1558.

Poyarkov, N.A., J.J.L. Rowley, S.S. Gogoleva, A.B. Vassilieva et al. (2015a). A new species of Leptolalax (Anura: Megophryidae) from the western Langbian Plateau, southern Vietnam. Zootaxa, 3931 (2): 221-252.

Poyarkov, N.A., E.N. Solovyeva, T.V. Nguyen, P. Geissler (2020a). On the taxonomic status of three enigmatic Indochinese frog species (Amphibia: Anura) described by L. G. Andersson. Zootaxa, 4834: 502-522.

Poyarkov, N.A., A.B. Vassilieva, N.L. Orlov, E.A.Galoyan, D.T.A. Tran et al. (2014). Taxonomy and distribution of narrow-mouth frogs of the genus Microhyla Tschudi, 1838 (Anura: Microhylidae) from Vietnam with descriptions of five new species. Russian Journal of Herpetology, 21 (2): 89-148.

Rakotoarison, A., M.D. Scherz, F. Glaw, J. Köhler, F. Andreone et al. (2017). Describing the smaller majority: integrative taxonomy reveals twenty-six new species of tiny microhylid frogs (genus Stumpffia) from Madagascar. Vertebrate Zoology, 67 (3): 271-398.

Rambaut, A., M.A. Suchard, D. Xie, and A.J. Drummond (2014). Tracer. Version 1.6 <http://tree.bio.ed.ac.uk/software/tracer/> Accessed on 4 October 2020.

Ronquist, F. and J. P. Huelsenbeck (2003). MrBayes 3: bayesian phylogenetic inference under mixed models. Bioinformatics, 19 (12): 1572-1574.

Sano, N., A. Kurabayashi, T. Fujii, H. Yonekawa, and M. Sumida (2005). Complete nucleotide sequence of the mitochondrial genome of Schlegel's tree frog Rhacophorus schlegelii (family Rhacophoridae): duplicated control regions and gene rearrangements. Genes \& Genetic Systems, 80 (3): 213-224.

Savage, J.M. (1975). Systematics and distribution of the Mexican and Central American stream frogs related to Eleutherodactylus rugulosus. Copeia, 1975: 254-306.

Seehausen, O., Y. Terai, I.S. Magalhaes, K.L. Carleton et al. (2008). Speciation through 
sensory drive in cichlid fish. Nature, 455 (7213): 620-626.

Seshadri, K.S., R. Singal, H. Priti, G. Ravikanth, M.K. Vidisha et al. (2016). Microhyla laterite sp. nov., a new species of Microhyla Tschudi, 1838 (Amphibia: Anura: Microhylidae) from a laterite rock formation in South West India. PLoS One, 11 (3): e0149727.

Shaffer, H.B., M. Gidis, E. McCartney-Melstad, K.M. Neal et al. (2015). Conservation genetics and genomics of amphibians and reptiles. Annual Review of Animal Biosciensces, 3: 23.1-23.26.

Smith, A.M., N.A. Poyarkov, and P.D.N. Hebert (2008). CO1 DNA barcoding amphibians: take the chance, meet the challenge. Molecular Ecology Notes, 8: 235-246.

Steinfartz, S., M. Weitere, and D. Tautz (2007). Tracing the first step to speciation: ecological and genetic differentiation of a salamander population in a small forest. Molecular Ecology, 16 (21): 4550-4561.

Tamura, K., G. Stecher, D. Peterson, A. Filipski, and S. Kumar (2013). MEGA6: molecular evolutionary genetics analysis version 6.0. Molecular Biology \& Evolution, 30 (12): 2725-2729.

Trifinopoulos, J., T.L. Nguyen, A. von Haeseler, and M.Q. Bui (2016). W-IQ-TREE: a fast online phylogenetic tool for maximum likelihood analysis. Nucleic Acids Research, 44: W232-W235.

Vassilieva, A.B., E.A. Galoyan, S.S. Gogoleva, and N.A. Poyarkov (2014). Two new species of Kalophrynus Tschudi, 1838 (Anura: Microhylidae) from the Annamite mountains in southern Vietnam. Zootaxa, 3796 (3): 401434.

Vences, M. and D.B. Wake (2007). Speciation, species boundaries and phylogeography of amphibians. In: Heatwole, H.H. and M. Tyler (eds.). Amphibian Biology, Vol. 6, Systematics. Surrey Beatty \& Sons, Chipping Norton: 2613-2669pp.

Vences, M., M. Gehara, J. Köhler, and F. Glaw (2012). Description of a new Malagasy treefrog (Boophis) occurring syntopically with its sister species, and a plea for studies on nonallopatric speciation in tropical amphibians. Amphibia-Reptilia, 33(3-4): 503-520.
Vences, M., M. Thomas, R.M. Bonett, and D.R. Vieites (2005a). Deciphering amphibian diversity through DNA barcoding: chances and challenges. Philosophical Transactions of the Royal Society B Biological Sciences, 360 (1462): 1859-1868.

Vences, M., M. Thomas, A. van der Meijden, Y. Chiari, and D.R. Vieites (2005b). Comparative performance of the 16S rRNA gene in DNA barcoding of amphibians. Frontiers in Zoology, 2 (1): 5 .

Via, S. (2001). Sympatric speciation in animals: the ugly duckling grows up. Trends in Ecology \& Evolution, 16 (7): 381-390.

Via, S. (2009). Natural selection in action during speciation. Proceedings of the National Academy of Sciences, 106: 9939-9946.

Vieites, D.R., K.C. Wollenberg, F. Andreone, J.Köhler, F. Glaw et al. (2009). Vast underestimation of Madagascar's biodiversity evidenced by an integrative amphibian inventory. Proceedings of the National Academy of Sciences, 106 (20): 8267-8272.

Vineeth, K.K., U. Radhakrishn, R. Godwin, S. Anwesha, K.P. Rajashekhar, and N. Aravind (2018). A new species of Microhyla Tschudi, 1838 (Anura: Microhylidae) from West Coast of India: an integrative taxonomic approach. Zootaxa, 4420: 151-179.

Wijayathilaka, N., S. Garg, G. Senevirathne, and N. Karunarathna (2016). A new species of Microhyla (Anura: Microhylidae) from Sri Lanka: an integrative taxonomic approach. Zootaxa, 4066 (3): 331-342.

Wollenberg, K.C., D.R. Vieites, F. Glaw, and M. Vences (2011). Speciation in little: the role of range and body size in the diversification of Malagasy mantellid frogs. BMC Evolutionary Biology, 11 (1): 217.

Zhang, M.H., L. Fei, C.Y. Ye, Y.F. Wang, B. Wang et al. (2018). A new species of genus Microhyla (Amphibia: Anura: Microhylidae) from Zhejiang Province, China. Asian Herpetological Research, 9: 135-148.

Zhao, Y., H. Meng, and L. Su (2018). The complete mitochondrial genome of the mixtured pygmy frog Microhyla mixtura (Anura, Microhylidae). Conservation Genetics Resources, 10 (3): 427-430. 